Invited review

\title{
Applications of proxy system modeling in high resolution paleoclimatology ${ }^{\text {厺 }}$
}

\author{
M.N. Evans ${ }^{\text {a,* }}$, S.E. Tolwinski-Ward ${ }^{\text {b }}$, D.M. Thompson ${ }^{\text {c }}$, K.J. Anchukaitis ${ }^{\mathrm{d}}$ \\ ${ }^{a}$ Department of Geology and Earth System Science Interdisciplinary Center, University of Maryland, College Park, MD, USA \\ ${ }^{\mathrm{b}}$ Institute for Mathematics Applied to Geosciences, National Center for Atmospheric Research, Boulder, CO, USA \\ ${ }^{c}$ Department of Geosciences, University of Arizona, Tucson, AZ, USA \\ ${ }^{\mathrm{d}}$ Department of Geology and Geophysics, Woods Hole Oceanographic Institution, Woods Hole, MA, USA
}

\section{A R T I C L E I N F O}

\section{Article history:}

Received 12 November 2012

Received in revised form

23 May 2013

Accepted 29 May 2013

Available online

\section{Keywords:}

Forward modeling

Observational network optimization

Data-model comparison

Hypothesis evaluation

Reconstruction

Uncertainty modeling

\begin{abstract}
A B S T R A C T
A proxy system model may be defined as the complete set of forward and mechanistic processes by which the response of a sensor to environmental forcing is recorded and subsequently observed in a material archive. Proxy system modeling complements and sharpens signal interpretations based solely on statistical analyses and transformations; provides the basis for observing network optimization, hypothesis testing, and data-model comparisons for uncertainty estimation; and may be incorporated as weak but mechanistically-plausible constraints into paleoclimatic reconstruction algorithms. Following a review illustrating these applications, we recommend future research pathways, including development of intermediate proxy system models for important sensors, archives, and observations; linking proxy system models to climate system models; hypothesis development and evaluation; more realistic multiarchive, multi-observation network design; examination of proxy system behavior under extreme conditions; and generalized modeling of the total uncertainty in paleoclimate reconstructions derived from paleo-observations.
\end{abstract}

(c) 2013 The Authors. Published by Elsevier Ltd. All rights reserved.

\section{Introduction}

Paleoclimatic reconstructions and their uncertainty estimates are generally derived from the inversion of transfer functions linking paleoclimatic observations to a climate variable, with outof-sample validation of the transfer function used to assess random and systematic uncertainties in the results (Sachs et al., 1977; Birks, 1995; Smerdon et al., 2011a; Christiansen, 2011; Tingley et al., 2012). Such paleoclimate reconstructions may put recent observations into a longer-term context (Jansen et al., 2007), enable direct comparison with the output of realistically-forced paleoclimatic modeling simulations (Schmidt, 2010; Hargreaves et al., 2011; Taylor et al., 2012; Schmidt et al., 2012, 2013), permit assessment of climate sensitivity to external radiative forcing (Schneider von Deimling et al., 2006; Schmittner et al., 2011; Hargreaves et al., 2012), and provide reasonable and potentially

\footnotetext{
This is an open-access article distributed under the terms of the Creative Commons Attribution-NonCommercial-ShareAlike License, which permits noncommercial use, distribution, and reproduction in any medium, provided the original author and source are credited.

* Corresponding author.

E-mail address: mnevans@geol.umd.edu (M.N. Evans).
}

independent constraints for interpreting other paleoenvironmental observations (Graham and Hughes, 2007; Graham et al., 2007).

These activities may require assumptions about the stationarity, linearity and/or spectral fidelity of the paleodata-climate relationship. They also require estimation of random and systematic uncertainties in the paleodata, extrapolation of the paleodata calibrations used in paleo-reconstructions (Mix et al., 1999; Huntley, 2012), and paleoclimate simulations to which the paleodata or reconstructions may be compared (Schmidt, 2010; Bradley, 2011). The validity of these assumptions is difficult to fully assess, as is the extent to which we can accurately identify the magnitude and characteristics of uncertainty in the reconstructions. Nevertheless, knowledge of both is critical as we attempt more sophisticated and detailed "piecing together of the past" (Tingley et al., 2012) from imperfect information. For instance, accurate assessment of uncertainties in paleoclimatic reconstructions is key for mechanistic climate change fingerprinting (Hegerl et al., 2007) via spatiallyresolved climate field reconstructions and paleodata-model comparisons (Mann et al., 2009a; Graham et al., 2011; Schmittner et al., 2011; Hargreaves et al., 2012; Schmidt et al., 2013).

Here we advocate addressing these problems using proxy system models. A generalized proxy system model is depicted in Fig. 1, and encapsulates a simplified representation of prior physical, 


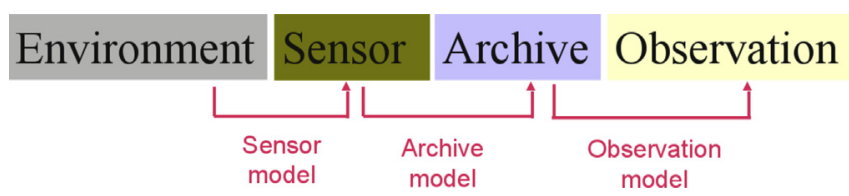

Fig. 1. Conceptual generalized proxy system model. An archive is the medium in which the response of a sensor to environmental forcing may be observed. A proxy system model is an idealized representation of the complete proxy system or selected components thereof.

chemical, biological and/or geological understanding of the ways in which environmental variation ultimately results in the observations used to retrieve paleoclimatic information. In this sense, these models are forward, even if they may be empirically-derived: the predictors are scientifically understood to cause variations in the predictands, and parameters are realistically constrained. Following the terminology and framework for proxy system modeling proposed by James Annan and the SUPRAnet working group, ${ }^{1}$ and following the ideas of Cohen (2003) and Lough and Cooper (2011), an archive is the medium in which the response of a sensor to environmental forcing is recorded (Fig. 1). Observations are made on archives. Because proxy systems are effectively filters of the climate system, sometimes in terms of time-dependent circulation and mixing processes (Khatiwala et al., 2001), we may clearly distinguish them from modeling of the climate system itself. Proxy system model subcomponents may be described that represent, for example, the behavior of the sensor in response to environmental forcing (sensor model), the way in which the sensor either creates or emplaces the signal into the archive (archive model), and the way in which observations are made on the archive (observational model). Explicit or implicit in any of these submodels may be the way in which the processes depend on filtering and integrating over time or space. Together with analytical and statistical frameworks, proxy system models may enable us to extract more accurate paleoclimate information from the available paleodata, as well as develop a clearer or more explicit description of their uncertainties.

To fully explore the potential of proxy system modeling, we begin with elements of the generalized model. Although only a component of the environment, climate is much more than a single reconstruction target such as surface temperature. Some examples of climatic variables that might be important for various sensors are net or photosynthetically-active radiation, pressure and winds, precipitation minus evaporation, and surface temperature (Fig. 2). Fields of these variables often exhibit large-scale spatial structure (Wallace, 1996b), have a pronounced and generally highly energetic annual cycle, and have characteristic patterns which may or may not be frequency-dependent (Wallace, 1996a; Huybers and Curry, 2006).

The sensor acts in response to the environment and leaves an imprint in the archive. The sensor model may realistically be comprised of physical, chemical and biological components, and be multivariate, seasonal and/or nonlinear or thresholded in its response to environmental or climatic variation. Different sensors, such as the upper continental crust (Huang et al., 2000; Mann et al., 2009b), trees comprising contiguous forests (e.g. Fritts (1976); Villalba et al. (2001)) and lakes (e.g. Williams and Shuman, 2008; Viau et al., 2012) may respond to environmental forcing with different temporal or spectral resolutions which arise from the nature of the sensor or the archive (e.g. Evans et al., 2002; Moberg et al., 2005 and see below). In turn, the degree to which their local

\footnotetext{
${ }^{1}$ http://caitlin-buck.staff.shef.ac.uk/SUPRAnet/.
}

response represents synoptic or global-scale spatial variation may also depend on a combination of location (Evans et al., 1998) and temporal resolution (Wallace, 1996a,b).

For example, consider the reef-building corals, which are colonies of stationary polyps which live within optimal ranges of light, temperature, salinity, nutrients, and turbidity. Depending on the interplay of calcification rate, carbonate density and extension (radial growth) rate, they produce aragonitic corallites in massive colonial structures within permissible ranges of environmental conditions (Fig. 3). The sensor response is thus multivariate, nonlinear and potentially seasonally-filtered in that coral growth will be suboptimal or nonexistent outside of optimal growing conditions.

The output of the sensor is imprinted on an archive, which may result from additional temporal, geological, biological, and/or chemical processes, and which may be explicitly represented by an archive model. In the case of the coral sensor described above, the archive is the massive aragonite structure formed by generations of polyps over time. Marine sediments are another important paleoclimatological archive (Fig. 4). They may be comprised of the commingled output of multiple sensors, including net inorganic, biogenic, and organic sedimentation, which in turn may be modified before observation by processes of dissolution, hydration, alteration, metabolism, mixing, sorting, transport, and compression. Archive models that incorporate one or more of these processes may be used to assess chronological uncertainty of paleodata time series (Burgess and Wright, 2003; Bronk Ramsey, 2008, 2009; Blaauw and Christen, 2011; Klauenberg et al., 2011; Parnell et al., 2011; Scholz and Hoffman, 2011; Anchukaitis and Tierney, 2012).

What are generally referred to as climate "proxies" are the actual observations that may be developed from an archive. This may be a subset of all possible observations we might make, and includes those used to estimate chronology. Maximum time resolution of observations may be analytically-determined or archivelimited. In general, the resulting time, frequency and signal resolution of age-modeled paleodata series is limited by number, frequency, time span, accuracy and precision of chronological observations and stratigraphic constraints, slope of the age-depth curve, replication, and the extent of mixing, transport, integration, diffusion and hiatuses imposed by the sensor, archive and observation processes (e.g. see Chatfield, 1989; Cook et al., 1995; Meese et al., 1997; Evans et al., 1999; Huang et al., 2000; Burgess and Wright, 2003).

For example, consider the science of dendrochronology, the study of tree rings (Douglass, 1919; Fritts, 1976; Vaganov et al., 2006). The sampling of the extant archive itself may involve highly nonrandom sampling by location or species to optimize and simplify interpretation of the observed sensor response to environmental forcing (Fritts, 1976). The potential observational suite (Hughes, 2011) includes all measurements which may be made during the part of the year for which the sample of trees produces woody material in the stem, with information from the non-growth season inferred from lagged-response processes or covariation within the environment itself. Potential observations include characteristics of the wood anatomy (Schweingruber et al., 1978); total, early-season and late-season incremental growth (Meko and Baisan, 2001; Griffin et al., 2011); radiocarbon and light stable isotopic composition (McCarroll and Loader, 2004); and wood chemistry (Guyette, 1991). From the commonly observed incremental growth observation, multiple partial and complete replicates may be used to establish chronology (Douglass, 1941; Stokes and Smiley, 1968; Fig. 5) and statistically isolate patterns of variance from site samples (Wigley et al., 1984; Cook and Kairiukstis, 1990) for which signal interpretations may be inferred. 

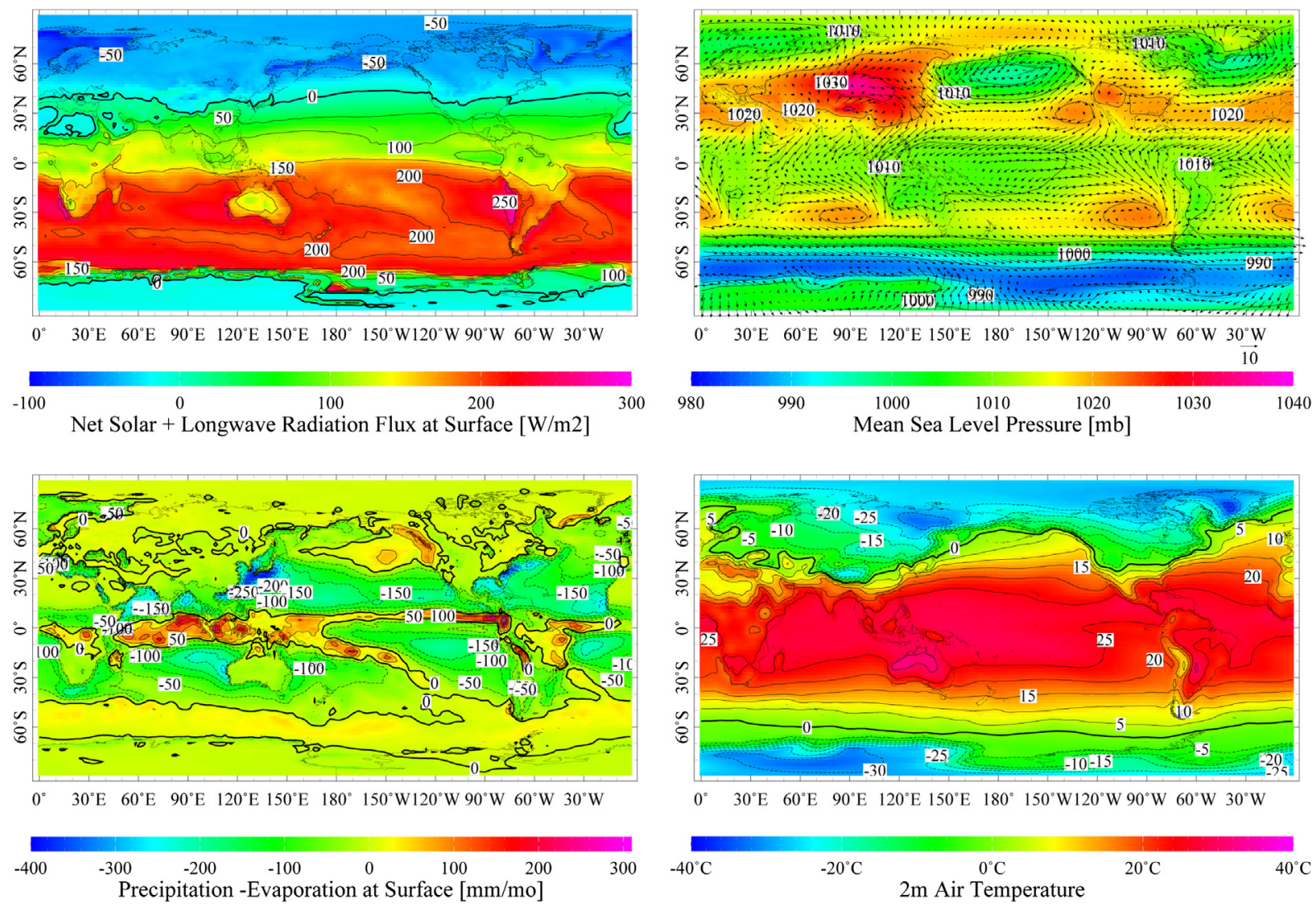

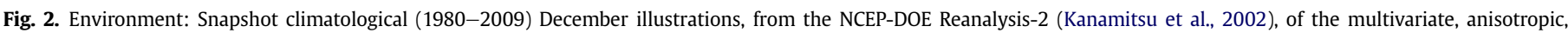

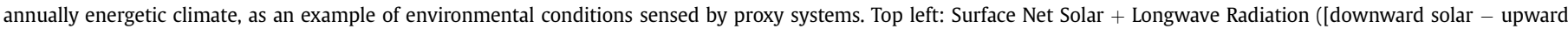

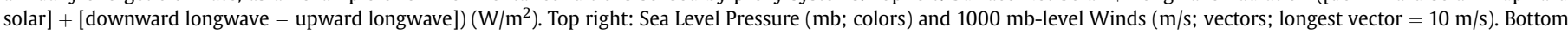

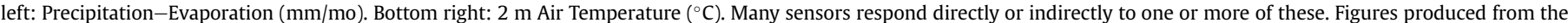
IRI Data Library using Ingrid (iridl.ldeo.columbia.edu).

\section{Applications of proxy system modeling}

In this section we illustrate, using examples from our own work, how application of the proxy system modeling paradigm (Fig. 1) allows us to perform network optimization, signal identification, uncertainty estimation, paleoclimatic reconstruction, and paleodata-climate model comparisons. In particular, we will focus on applications of intermediate-level models in the context of high-resolution paleoclimatology. By intermediate, we follow the descriptive hierarchy in the climate system modeling literature (Trenberth, 1995). In the paleo context, intermediate proxy system models are mechanistically-based and more complex than univariate-linear in their response to an environmental forcing; but the full known complexity of the complete proxy system is only very partially represented. By sacrificing complexity, however, intermediate proxy system models may achieve a reduction in sensitivity of results, through a reduction on degrees of freedom and number of specifiable parameters (Evans et al., 2006). For many proxy systems or cases, intermediacy of a second sort may arise because we can learn from a simplified representation of the complete proxy system. For instance, to study uncertainties in borehole temperature inversions, we need not model archive formation. Similarly, we may be able to perform signal identification studies in tree-ring width chronologies even if we neglect the rather complex archive and observational models. In many cases, we will use the term sensor model (Fig. 1) to refer here to the combination of an intermediate proxy system model having an intermediate sensor component, but trivialized archive and/or observational model components. For further exploration, the reader is referred to additional illustrations of applications of proxy system modeling (Table 1 ).

\subsection{Observational network design}

Optimal sampling networks for paleoclimatic reconstruction may be identified using proxy system models, estimated uncertainty of paleo-observations, and known patterns in the climate field to be reconstructed (Bretherton and McWilliams, 1980; Bradley, 1996; Evans et al., 1998). In the paleoclimatological context, Bradley (1996) addressed observational network design for global annual mean surface air temperature as a function of existing paleo-observations. Evans et al. (1998) designed sampling networks for observation of large-scale patterns in the global SST field from a small hypothetical set of potential coral sampling sites, and for a range of plausible observational uncertainties. The identified networks generally resolved variance associated with ENSO by sampling and replicating at sites in the central and eastern equatorial Pacific.

As an example, consider the sensor model for the oxygen isotopic composition of $\alpha$-cellulose $\left(\delta^{18}\right)$ extracted from wood (Barbour et al., 2004), which may be simplified for the special case of tropical environments (Evans, 2007). In this sensor model, $\delta^{18} \mathrm{O}_{\alpha \text {-cellulose }}$ may be written as a multivariate function of monthly variations in precipitation, temperature and relative humidity. This sensor model is computationally cheap enough to be run everywhere on a $0.5^{\circ} \times 0.5^{\circ}$ terrestrial grid for the global tropics. We can 


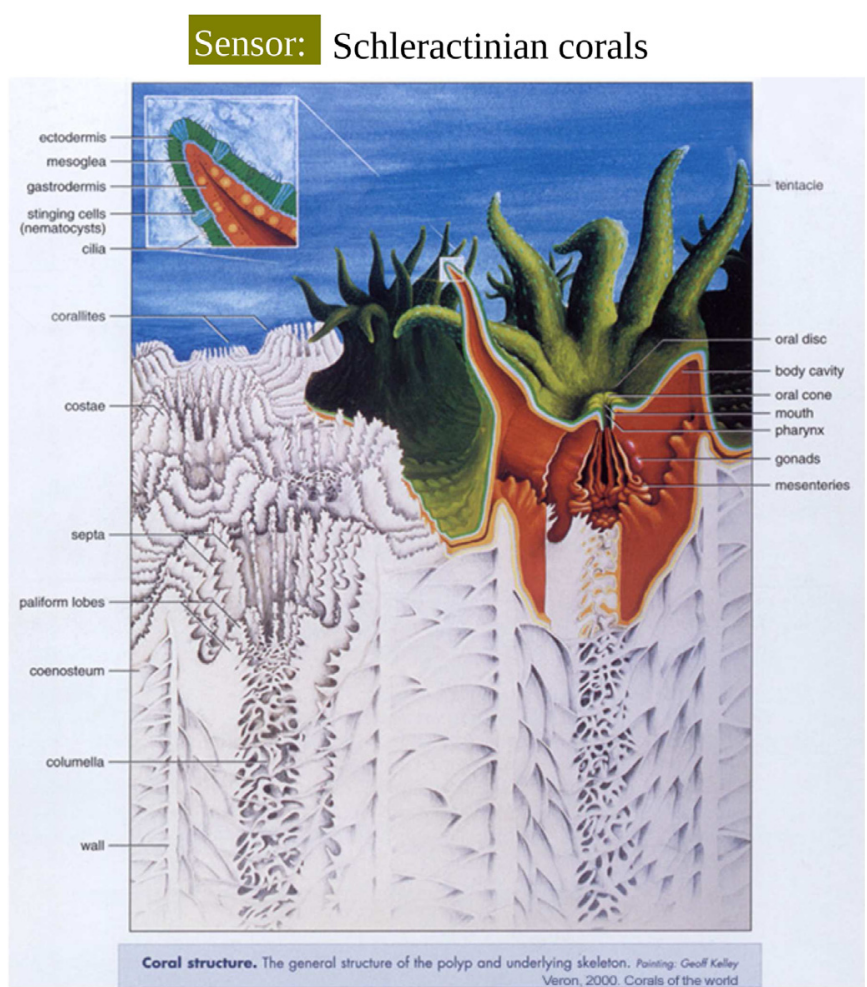

Fig. 3. Sensor: the general structure of a massive, colonial, reef-building Scleractinian ("stony") coral polyp and its underlying skeleton (corallite) (Veron, 2000, (painting by G. Kelly)). The anemone-like polyp lives on the outermost surface of its skeleton and colony, and catches prey that floats by using its tentacles, which have stinging cells. These corals coexist symbiotically with photosynthetic zooxanthellae living within their tentacles. Over time the animal secretes skeletal aragonite in characteristic and supportive structures (costae, septa, lobes, coenostea, columellae, and walls), building an archive on which observations may be made. Reproduced with permission from J.E.N. Veron.

then find the first principal component of the sensor model output, and correlate it with the tropical sea surface temperature (SST) anomaly field (contours in Fig. 6). The leading pattern in the sensor model output is associated with a pattern in SST that resembles that of the oceanographic signature of the El Niño-Southern Oscillation (ENSO). Analogously, the correlation of the first PC of the tropical SST field with the sensor model output field (colors in Fig. 6) can be interpreted as the pattern in the sensor model output associated with ENSO activity. If the sensor model is indeed an adequate representation of the true sensor model, then the colors indicate where we should sample (neglecting downscaling; e.g. (Wilby and Wigley, 1997; Reichert et al., 1999; Slonosky et al., 2001; Benestad et al., 2007)) to obtain actual $\delta^{18} \mathrm{O}_{\alpha \text {-cellulose }}$ measurements which give us information about past ENSO activity. Because the sensor model as yet only has limited direct observational and modeling support (Anchukaitis et al., 2008; Anchukaitis and Evans, 2010; Brienen et al., 2012), this observing map may be considered a scientific working hypothesis rather than an observing network design solution. The true optimal observing network may appear differently, due to biogeographical and species-specific effects, the importance of sensor, archive and observational effects on the complete proxy system, and the stationarity of teleconnections in the tropical ocean-atmosphere system.

\subsection{Signal interpretation}

Proxy system models may be applied within periods for which we have direct observation of their environmental inputs. This allows us to test whether our interpretations of actual observations arising from proxy systems, perhaps based primarily on statistical modeling and empirical argument (Cook et al., 1999), is consistent with the explicit representation described in the corresponding proxy system model. Because of the large uncertainties at any single site and the difficulty of exactly matching modeled and observed networks in space and/or in time, we often develop such comparisons using diagnostics drawn from regional-to-global and seasonal-to-annual scale experiments. If the resulting large-scale model composites are significantly correlated with similarly large-scale composites derived from actual observations, we may infer that the sensor model is sufficient to explain the variations observed in the actual observations. We can then diagnose the model to examine the likely environmental controls on the actual observations.

As an illustration, the sensor model of Vaganov and Shashkin (Vaganov et al., 2006) for standardized tree ring width (TRW) variations as a nonlinear function of daily temperature, precipitation, site latitude (used to calculate insolation), cambial processes, and parameters, may be forced with daily meteorological observations within a given region as inputs. Anchukaitis et al. (2006) used the Vaganov-Shashkin model in a case study for the southeastern United States region, and found that with a single and constant set of modeling parameters, correlation between the first PC of simulated and observed TRW data was significant $(r=0.61$, $p<0.0001, n=66$ ) for the 1920-1985 comparison interval. By diagnosing the modeled response to the environmental forcing, Anchukaitis et al. (2006) showed that the dependence of TRW on environmental forcing was systematically changing with time (Fig. 7). Specifically, they found that before 1976, modeled growth was limited by spring precipitation (Anchukaitis et al., 2006). However, after 1976, it appeared that a trend toward drier summers caused July and August precipitation to become more important in determining ring width (Fig. 7). This result illustrates how a simple but realistically nonlinear and multivariate sensor model may permit a more accurate interpretation of the actual observations in terms of the environmental forcing (Anchukaitis et al., 2006), relative to that inferred from the simpler, stationary, linear empirical-statistical models generally applied in dendroclimatic data calibration and reconstruction (for instance, see Cook and Pederson, 2011; Vaganov et al., 2011).

\subsection{Uncertainty analysis}

Proxy system models may also be used to transform direct climate observations or climate model simulations into estimates in a "native" paleo-observational variable, and thereby make direct comparisons with actual observations. This approach complements the inversion of sparse paleo-observations into paleoclimatic reconstructions (Mann et al., 1998; Cook et al., 1999; Evans et al., 2002; Mann et al., 2008) for such purposes (Mann et al., 2009a), but avoids the uncertainties arising from sparse paleoobservational networks and the stationarity, univariate dependence, frequency and normality assumptions underlying the statistical inversion process. Instead, it allows us to identify or gauge: uncertainties in our process understanding of proxy systems, from environmental forcing to observations via sensor, archive and observational modeling; error and bias arising from limited observational networks; and/or uncertainties in the external forcing and physics of climate models.

For example, the oxygen isotopic composition of the aragonite secreted by reef-building corals $\left(\delta^{18} \mathrm{O}\right)$ is a function of the temperature-dependent equilibrium isotopic fractionation during aragonite precipitation, superimposed on variations in the isotopic composition of seawater and species-dependent "vital effects". The 


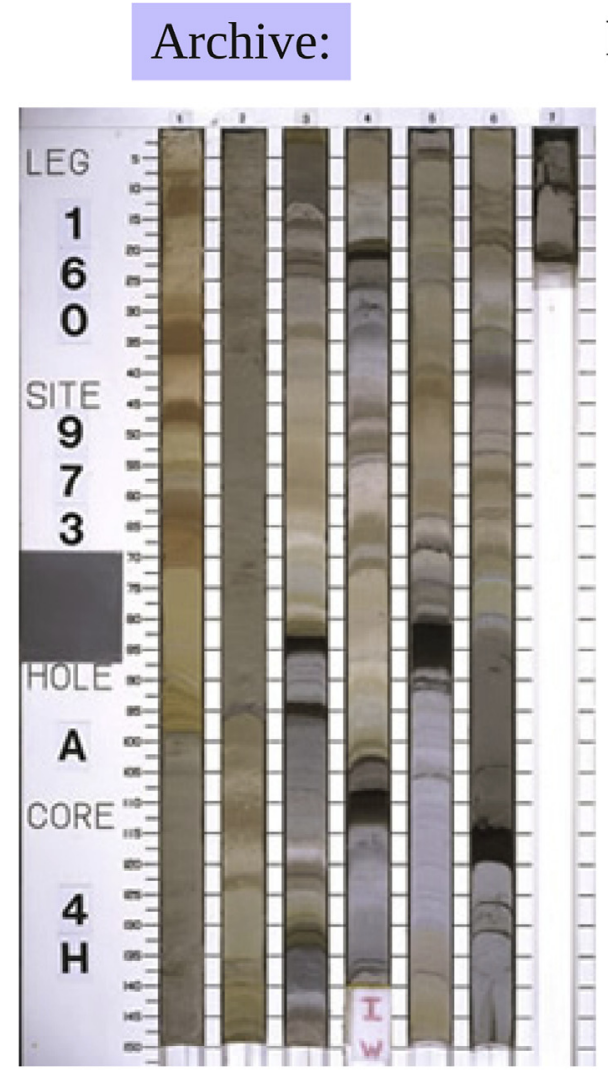

Marine sediments

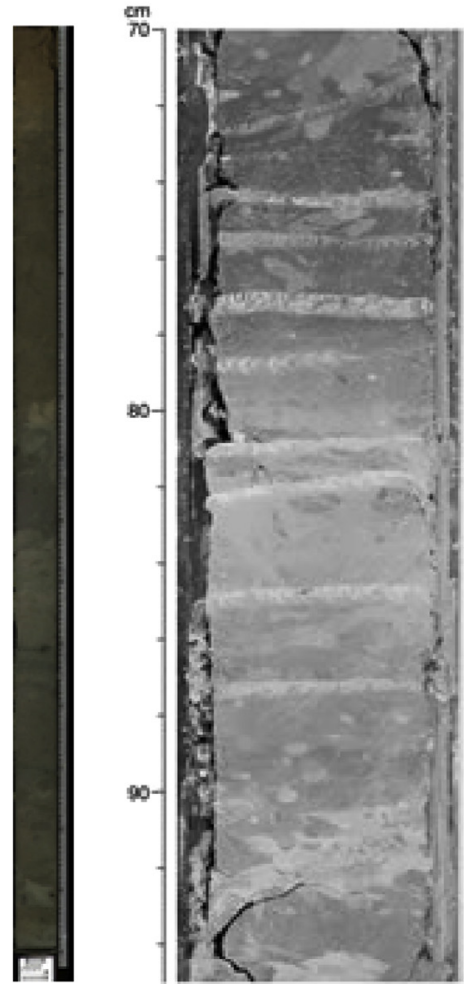

Fig. 4. Archive: whole-core visible light image of marine sediment core 4H, Hole A, Site 973, Leg 160, taken by the Integrated Ocean Drilling Project - United States Implementing Organization (IODP-USIO) IODP/TAMU (2010). Reproduced with permission of IODP/TAMU.

\section{Observation:}

Tree ring width chronology

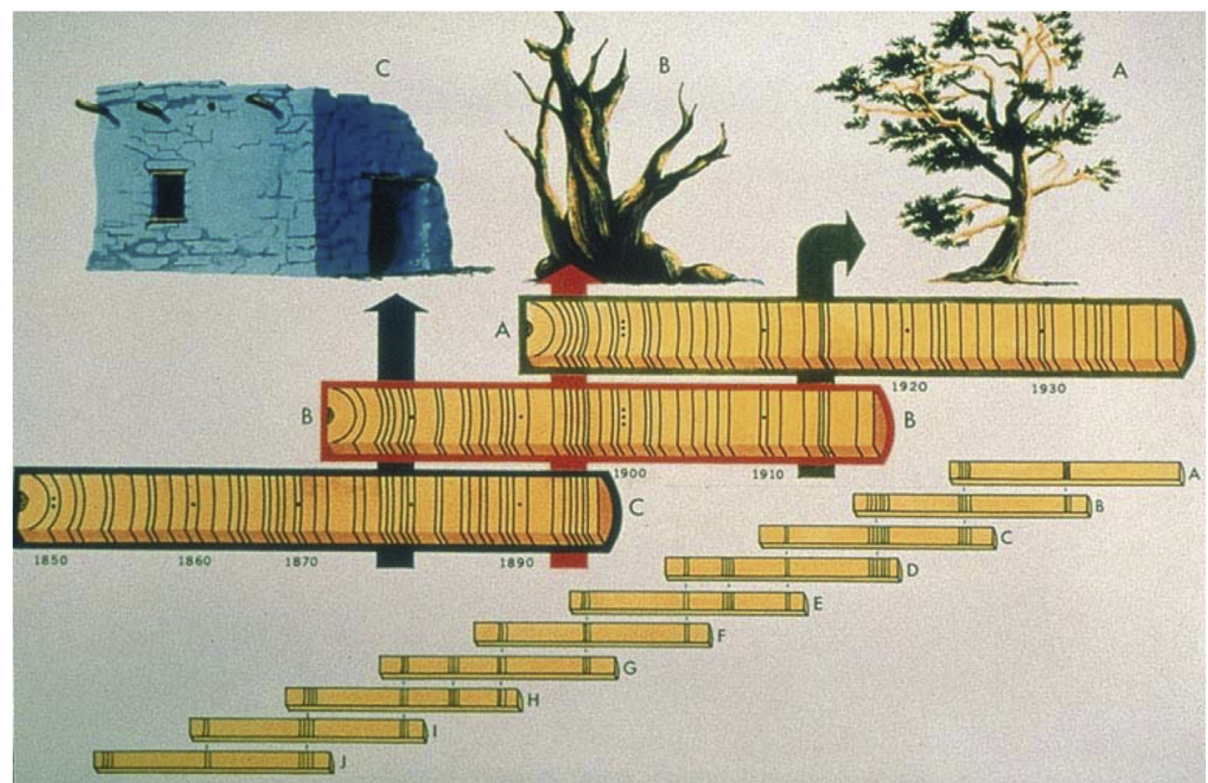

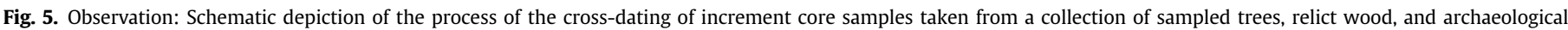

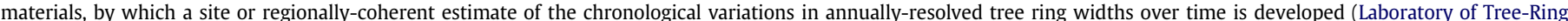

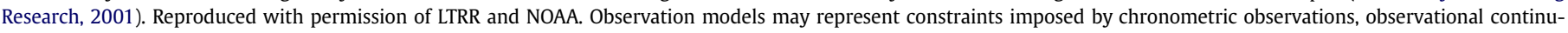
ity, frequency and replication, stratigraphy and sensor or archive-imposed mixing, transport, integration or diffusion processes. 
Table 1

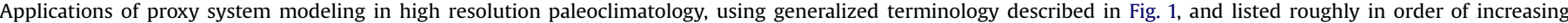

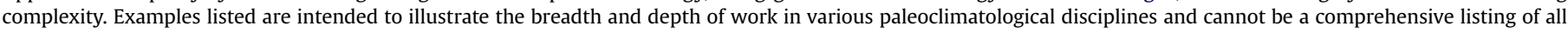

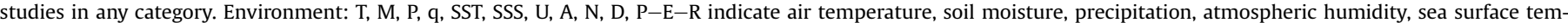

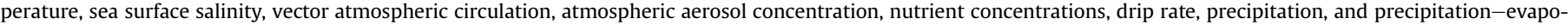

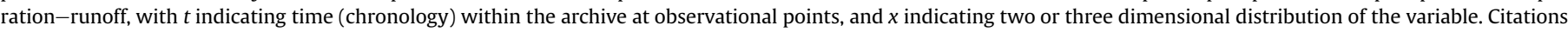

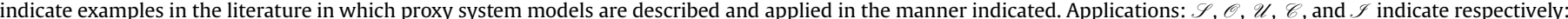

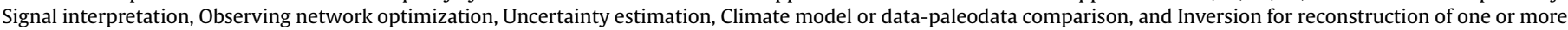
of the environmental variable(s) listed from the observations modeled as a function of environment, sensor, archive and/or observational processes.

\begin{tabular}{|c|c|c|c|c|c|}
\hline \multicolumn{6}{|c|}{ Applications of proxy system modeling in paleoclimatology } \\
\hline Environment & Sensor & Archive & Observation & Reference & Application \\
\hline $\mathrm{SST}(\mathrm{t}), \mathrm{SSS}(\mathrm{t})$ & Coral & Colony & Stable isotopes & Thompson et al. (2011) & $\mathscr{S}, \mathscr{C}$ \\
\hline $\mathrm{t}$ & Watershed & Sediments & Radiocarbon & Blaauw and Christen (2011) & $\mathscr{U}$ \\
\hline $\mathrm{T}(\mathrm{t})$ & Rock & Borehole & $\mathrm{T}(\mathrm{z})$ & Huang et al. (2000) & $\mathscr{I}$ \\
\hline $\mathrm{T}(\mathrm{t})$ & Ice sheet & Ice core & Stable isotopes & Severinghaus and Brook (1999) & $\mathscr{S}, \mathscr{J}$ \\
\hline $\mathrm{T}(\mathrm{t}), \mathrm{M}(\mathrm{t})$ & Trees & Wood & Ring width & Vaganov et al. (2011) & $\mathscr{S}$ \\
\hline $\mathrm{T}(\mathrm{t}), \mathrm{P}(\mathrm{t}), \mathrm{q}(\mathrm{t})$ & Tropical trees & Wood & Stable isotopes & Evans (2007) & $\mathscr{S}, \mathscr{O}$ \\
\hline $\mathrm{T}(\mathrm{t}), \mathrm{M}(\mathrm{t})$ & Lake & Sediments & $\begin{array}{l}\text { Relative abundance of } \\
\text { pollen species }\end{array}$ & $\begin{array}{l}\text { Haslett et al. (2006), } \\
\text { Wahl et al. (2012) }\end{array}$ & $\mathscr{I}, \mathscr{U}$ \\
\hline$A(t), U(t, x)$ & Ice sheet, ocean & Ice \& sediment cores & Dust deposition rate & Mahowald et al. (1999) & $\mathscr{C}$ \\
\hline$P(t), D(t)$ & Cave & Speleothem & $\begin{array}{l}\text { Stable isotopes, } \\
\text { elemental ratios }\end{array}$ & $\begin{array}{l}\text { Truebe et al. (2010), } \\
\text { Stoll et al. (2012) }\end{array}$ & $\mathscr{S}, \mathscr{I}$ \\
\hline $\operatorname{SST}(x), \operatorname{SSS}(t, x), U(x), P-E-R(x, t)$ & Oceans & Marine sediments & Stable isotopes & Schmidt (1999) & $\mathscr{S}, \mathscr{U}, \mathscr{C}$ \\
\hline $\mathrm{N}(\mathrm{x}, \mathrm{t}), \mathrm{U}(\mathrm{t}, \mathrm{x}), \varepsilon(\mathrm{t}, \mathrm{x})$ & Oceans & Seawater, marine sediments & Stable isotopes & Somes et al. (2010) & $\mathscr{S}, \mathscr{U}, \mathscr{C}$ \\
\hline$T(x, t), P(x, t)$ & Lake & Vegetation & $\begin{array}{l}\text { Pollen assemblages, } \\
\text { plant functional type }\end{array}$ & Guiot et al. (2009) & $\mathscr{S}, \mathscr{U}, \mathscr{C}, \mathscr{T}$ \\
\hline
\end{tabular}

thermodynamic influence (O'Neil et al., 1969) may be approximated (Grossman and $\mathrm{Ku}, 1986$ ) as a linear function of sea surface temperature (SST) (Weber and Woodhead, 1972); the seawater isotopic composition influence may be approximated in terms of sea surface salinity (SSS), which (like seawater oxygen isotopic composition) will vary with net freshwater flux from the mixed layer (Fairbanks et al., 1997). We can thus write down a simple bivariate linear sensor model for oxygen isotopic anomaly in coralline aragonite which is driven by variations in SST and SSS (Thompson et al., 2011). The coefficients are estimated a priori from analysis of contemporaneous observations of SST and coral $\delta^{18} \mathrm{O}$ (Evans et al., 2000; Lough, 2004) and SSS and seawater $\delta^{18} \mathrm{O}$ (LeGrande and Schmidt, 2006), respectively.

To make a direct comparison between a sparse network of actual coral observations and model simulations describing the response of the tropical ocean-atmosphere system to climate change (sensu Meehl et al., 2007), we can drive this sensor model with output from 20th century climate model simulations (Brown et al., 2008) forced with realistic 20th century external climate forcings (Forster et al., 2007), and compare the results to actual $\delta^{18} \mathrm{O}$ data (Thompson et al., 2011). Fig. 8 shows such a comparison in the state space represented by the spatial correlation between the trend and ENSO patterns (change in mean state) on the $x$-axis and the ratio of ENSO-related variance in the latter half of the study interval relative to that in the first half of the study interval (change in variance) on the $y$-axis. Thompson et al. (2011) found that modeled and observed $\delta^{18} \mathrm{O}$ occupied different regions of the state space. The reason for this disagreement is likely some combination of oversimplicity in the sensor model, systematic uncertainty in the coral-derived observations arising from the limited observing network, and systematic error in the covariance between temperature and salinity in the climate model simulations (Thompson et al., 2011). The results provide a basis for further investigating each of these uncertainties (Russon et al., 2013; Thompson et al., 2013).

\subsection{Paleoclimate reconstruction}

Proxy system models may also serve as mechanistic constraints on seasonal-to-annual resolution paleomodeling and paleoclimate

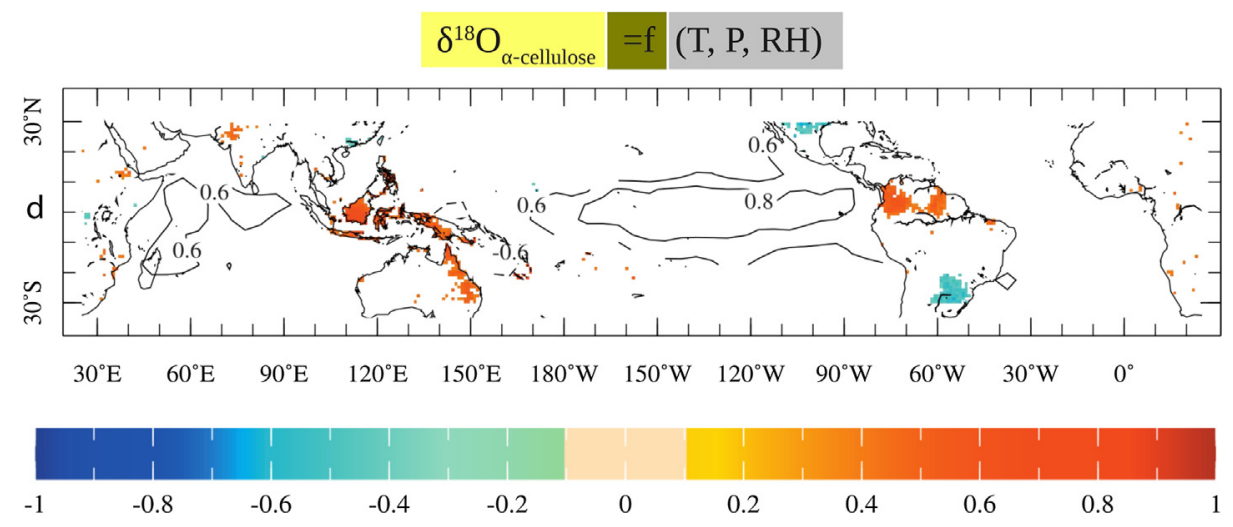

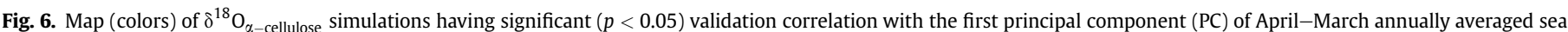

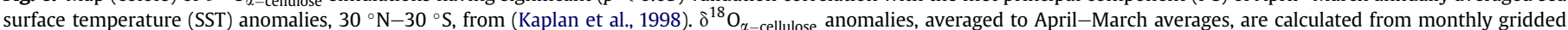

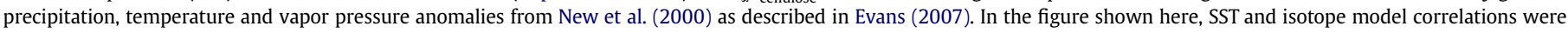
calculated for the 1901-1950 period, based on principal components estimated from the 1951-2002 period. After Evans (2007). 


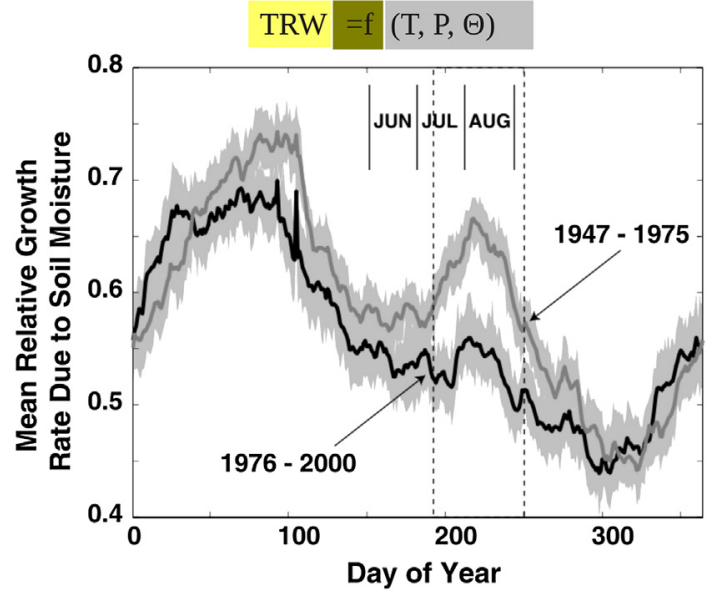

Fig. 7. Dimensionless Vaganov-Shashkin modeled mean growth rates due to soil moisture vs. day of year for regional southeastern United States tree ring width (TRW) simulations, for the period 1947-1975 (heavy gray line) and for the period 1976-2000 (heavy black line). Shaded regions are 95\% bootstrapped confidence intervals about the means. "JUN JUL AUG" indicates the summer months; dashed vertical lines indicate the interval in which a change after 1975 to a more late-season moisture-limited growing season, is inferred. After Anchukaitis et al. (2006).

reconstructions (LeGrande et al., 2006; Hughes and Ammann, 2009). In this context, the models may provide the relationship between paleo-observations and the environmental conditions most likely to have produced them, even for multivariate and nonlinear proxy systems (Schmidt, 1999; González-Rouco et al.,

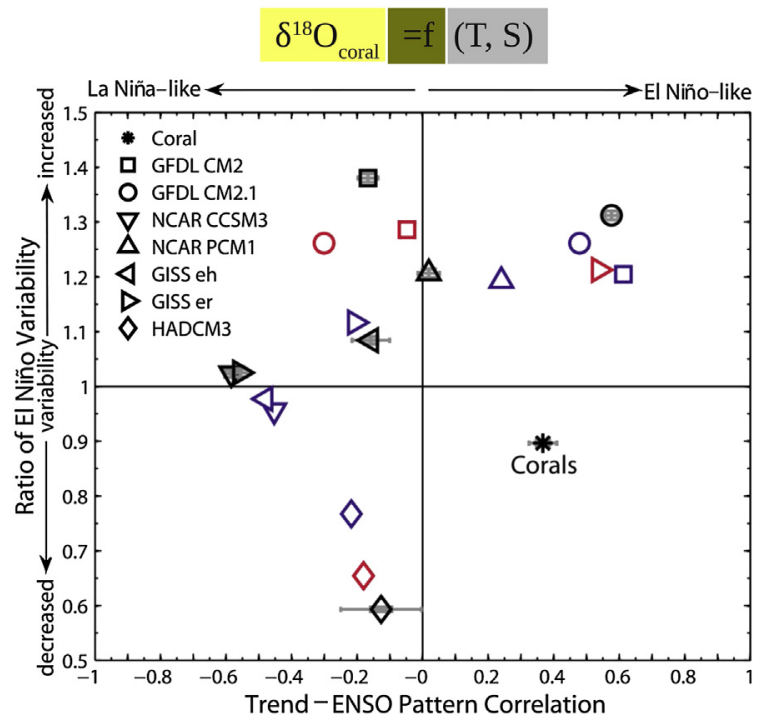

Fig. 8. State space model-data comparison of the 20th century response of tropical Pacific mean state and ENSO to warming in the global oceans, via modeled and observed $\delta^{18} \mathrm{O}$. The asterisk labeled "Corals" indicates the position in this space as represented by an actual network of coral $\delta^{18} \mathrm{O}$ data. Open symbols indicate the positions in this space occupied by the corals simulated from climate-modeled sea surface temperature (SST) and sea surface salinity (SSS) at the coral locations using a forward sensor model of $\delta^{18} \mathrm{O}$. Colored symbols show the positions in space occupied by corals simulated from climate-modeled SST (blue) or SSS (red) alone. Horizontal axis: Spatial correlation of the secular trend and ENSO patterns; positive (negative) values indicate the (negative) values indicate that the warming (cooling) trend and the trend and ENSO Patterns are correlated (anticorrelated). Vertical axis: Ratio of ENSOpattern temporal variance in the most recent 45 years, relative to that in the earlier 45 years of the period 1895-1985. Higher (lower) ratio indicates increased (decreased) ENSO-related variance in the last half of the 20th century relative to the first half of the 20th century. After Thompson et al. (2011).
2006; Guiot et al., 2009; Garreta et al., 2010; Stoll et al., 2012). Consider again the sensor model for tree ring widths, which has recently been simplified to rely only on monthly temperature, precipitation, site latitude and parameters as inputs (TolwinskiWard et al., 2011a,b). This model has no explicit biological sensor component outside of its representation of the dendrochronological principle of limiting factors (Fritts, 1976). In acknowledgment of its foundations in the Vaganov-Shashkin model described previously, it is known as "VS-Lite".

VS-Lite has been applied as a data level constraint in Bayesian hierarchical modeling (BHM) reconstructions of monthly local surface temperature and soil moisture. Reconstructions using a single series of tree ring width observations per site are inherently indeterminate: a series of variations in the observed TRW could arise from many different combinations of environmental forcing, because tree ring growth may respond to temperature variability, moisture variability, or a combination of both (Tolwinski-Ward et al., 2013b). The BHM framework reflects this feature of the problem explicitly by using the VS-Lite model to relate the data constraints to bivariate climatic variations within the hierarchical model. The reconstructions consist of joint posterior probability distributions for monthly-resolution temperature and moisture climate histories, conditional on the observed TRW data, a simple statistical climate-process model for local temperature and soil moisture covariations, and model parameters (Tolwinski-Ward et al., 2013a,b).

Extending the approach taken in pseudoproxy experiments (PPEs; Smerdon (2012)), we can test the ability of the methodology to accurately extract the true applied environmental forcing by replacing actual TRW with TRW simulated using VS-Lite (Tolwinski-Ward et al., 2013b). Synthetic (therefore, known) climate and ring-width time series were generated for a 30-year "calibration interval", in which temperature, by construction, was growth-limiting. Ring widths were also generated for a second $30-$ year interval in which the simulated climatology was shifted relative to the calibration interval. By design, the warmer and drier climatology in this latter interval resulted in simulated moisturecontrolled tree-ring growth. A Bayesian hierarchical model using VS-Lite as a data-level constraint was then used to estimate the climatic targets in this "validation" interval. Fig. 9 (left panel) shows contours containing $95 \%, 75 \%, 50 \%, 25 \%$, and $10 \%$ of the marginal prior and posterior probability densities of the change in temperature and soil moisture climatology for the reconstruction interval relative to the calibration interval, in units of calibration-interval standard deviation of each variable. The joint prior distribution of the shift in climatology is Gaussian and centered on no change: $\Delta T=\Delta M=0$. However, the posterior is clearly non-Gaussian. Its banana-like shape indicates that the reconstruction-interval ringwidth simulations could have resulted from either drier and warmer conditions, or else wetter conditions at temperatures typical of the calibration interval. The nonlinear association between probable values of the two climatic variables results from the representation of the nonlinear control of tree-ring growth that is built into VS-Lite.

A probabilistic reconstruction of climate during the medieval years 1080-1129 was also performed using the same methodology, but conditioning on both observed ring-width and carbon isotopic data from the Methuselah Walk site in the White Mountains of California. The period 1895-1980 is used to estimate the parameters of VS-Lite for modeling ring width variations, as well as the relationship of the isotope data to the soil moisture climatology. Fig. 9 (right panel) shows non-Gaussian posterior probability density in this case as well, this time exhibiting some bimodality. In this case, if VS-Lite is a reasonable representation of the sensor model for the Methuselah Walk tree ring width chronology, then the most probable explanation is slightly wetter and substantially 


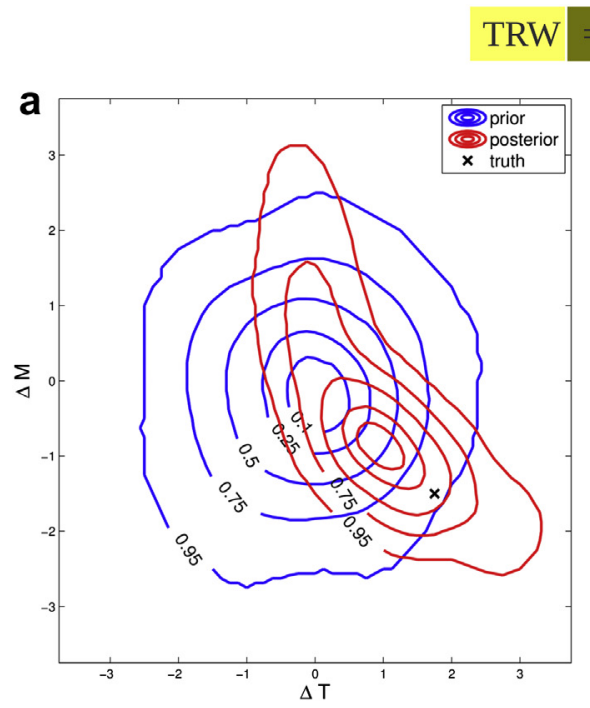
$(\mathrm{T}, \mathrm{M}, \Theta)$

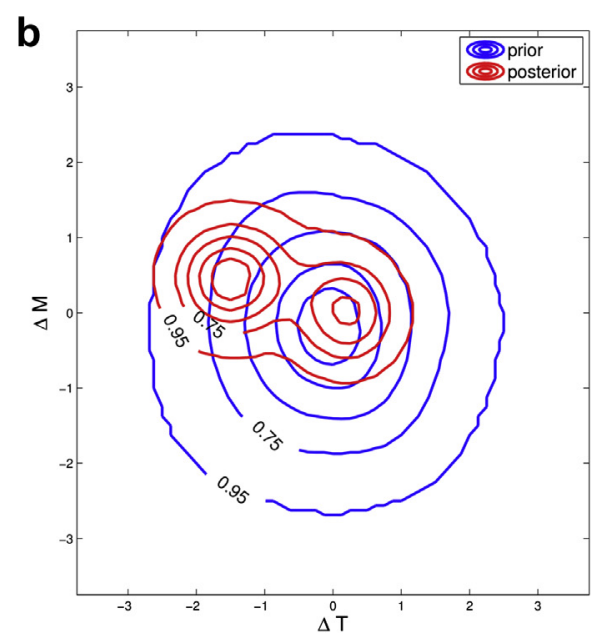

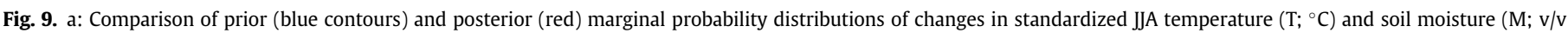

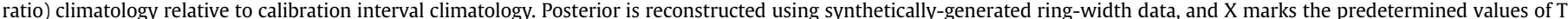

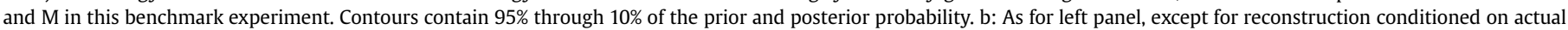

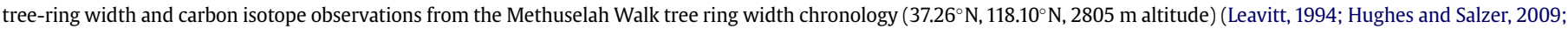
Salzer et al., 2009; Leavitt, 2013). After Tolwinski-Ward et al., (2013b).

cooler reconstruction-interval conditions. However, the paleodata is nearly equally likely to have arisen from climatological values of temperature and soil moisture, a result that might arise from the combination of the indeterminacy of the problem, uncertainty in the observations, and simplicity of VS-Lite. By using a realistically nonlinear and multivariate proxy system model, we can place and contextualize probabilities on potentially indeterminate underlying climatic variations, given observational and proxy system modeling uncertainty (Tolwinski-Ward et al., 2013b).

\section{Discussion}

With the recognition of the value of proxy system models for an increasing variety of environmental forcings, sensors, archives, observations, and applications (Section 2, Table 1), we make the following recommendations for future research.

\subsection{Develop new intermediate proxy system models for important sensors, archives, and observations}

Forward models for many proxy systems already exist and have been used to interpret records from these archives, including lakes (Shanahan et al., 2007; Conroy et al., 2008; Lyons et al., 2011; Tierney et al., 2011; Steinman et al., 2012), ice cores (Brönnimann et al., 2012), and speleothems (Baker and Bradley, 2010. Wackerbarth et al., 2010; Baker et al., 2012; Stoll et al., 2012). Where full complexity models for proxy systems exist, we need to adapt them for the additional applications described here, which in some cases require much lower dimensionality, generalization, and relative insensitivity to specification of fixed parameters. Where highly simplistic models exist, we need to examine whether additional realistic complexity provides additional validated modeling skill and is supported by observations and process studies of the proxy systems. Such intermediate complexity proxy system models strike a practical balance between more realistic representation of the multivariate and nonlinear processes underlying many proxy systems, without requiring specification of a relatively large number of unconstrained tunable parameters. For instance, we need to link sensor models (Graham and Hughes, 2007) to archive and observation models for multiproxy lake archives, including geochemical pollen and sediment facies observations (Cohen, 2003), and we need a mechanistic model for the vast dataset of maximum latewood density observations from the tree-ring archive. To best exploit the information contained within hardwon observational datasets, we need to explicitly model the sensor, archive and observational components of proxy systems. For instance, for the multivariate observations developed from high latitude and altitude ice core archives, we may need proxy system modeling of mass balance, chemistry, thermodynamics, dynamics, and chronology for interpreting gas and aqueous phase isotopic composition and dust deposition rates observed in ice sheets (Severinghaus and Brook, 1999; Thompson, 2000; LeGrande and Schmidt, 2009; Mölg et al., 2009). In some cases, transfer functions (Kipp, 1976) may not be easily derived, because of the nature of the complete proxy system (Cohen, 2003) and inability to calibrate against direct observations of environmental forcings. Nevertheless, such models may be driven forward as a means to quantify interpretations and uncertainty as a function of multiple hypothesized environmental forcings.

\subsection{Link proxy system models to climate system models}

Many earth system models (ESMs) now simulate coupled oceanic and atmospheric circulation, interactive land surface processes, ice sheets and sea ice, and carbon chemistry, and also model many conservative tracers which may be directly observed (Schmidt, 1999; Vuille and Werner, 2005; Schmidt et al., 2007; LeGrande and Schmidt, 2008). By offline coupling of climate models and proxy system models (i.e. using climate model output as input to proxy system models), we can bring the models into the "space" of the paleo-observations. In doing so, we attach mechanistic understanding of the proxy system to internally-consistent and mechanistic simulation of the environment as it is sensed by proxy systems, recorded in archives, and observed by paleoclimatologists. It avoids some of the potentially invalid assumptions in the back-transformation of paleo-observations into estimates of 
climate variability for the purposes of comparing climate model output and paleo-observations.

\subsection{Create and evaluate testable hypotheses}

If proxy system models represent our understanding of the processes that create observations of past climates, then we should use them, with historical observations, idealized environmental inputs, or inputs from climate system models to predict what we should observe in actual paleoclimate observations. TolwinskiWard et al., 2013b) found that probabilistic reconstructions of bivariate climate that use VS-Lite to relate the data to the past climatic forcing assign probability mass to both moisture-limiting and temperature-limiting climate histories. Thus, if VS-Lite is a reasonable representation of the actual proxy system, then the data cannot rule out, but may imply, by posterior joint probability density function of the reconstruction, a switch in the controls on tree-ring growth caused by a nonstationary climate. More generally, apparent nonstationarity in sensor, archive or observational proxy system models (D'Arrigo et al., 2008) - such as the so-called "divergence" problem in dendrochronology - which is potentially superimposed on nonstationarity in the climate itself (Cole and Cook, 1998), is a general question that could be addressed using proxy system models in a variety of contexts. It is also possible to identify potential non-uniqueness in the origins of paleoobservations as a consequence of multiple climate variables (e.g. Brönnimann et al., 2012), evaluate the expected degree of similarity in related or co-located archives given the same climate variability (e.g. Baker et al., 2012), and determine the relative importance of specific environmental factors given multiple possible influences on the proxy system (e.g. Shanahan et al., 2007; Steinman et al., 2010; Lyons et al., 2011).

\subsection{Design more realistically optimal sampling networks}

With the establishment of testable and specific research hypotheses, observing networks may be proposed that aim to maximize the precision and accuracy of reconstruction of particular climatic patterns, climatic variance, or events, based on either existing or potential data collections (Evans, 2007; Schmidt, 2010). With respect to extracting maximum information from the existing paleodata database, a combination of the choices made while sampling archives, and the simple limitations that are imposed by sensor distribution and sampling considerations, result in an observing network for the past millennium (Fig. 10, open black squares) which is highly heterogeneous in space, time, and observation type. For example, tree-ring observations are found in terrestrial locations and are concentrated in the extratropical Northern Hemisphere; borehole-derived observations are found in terrestrial locations and concentrated in the extratropical Northern and Southern Hemisphere. High resolution marine sedimentderived observations are generally found in the shallow and productive margins, and are concentrated in the Atlantic Basin. Reef coral archives typically exploited in paleoclimatology are found in the warmest tropical latitudes and are constrained by locations of fringing reefs, barrier reefs, and island atolls. Ice archives are preserved only at high altitudes and latitudes. In all cases the technical difficulty and cost of extracting samples or observations from these archives, and the tendency for younger materials to be more common and well-preserved than older ones, produces further sampling biases. For these and other reasons, very few (if any) studies have taken full advantage of the complete existing multisensor, archive and observational paleodatabase.

Some of the imprint of these biases in climate field reconstructions arising from the available observational sampling network has been isolated and studied in experiments simulating the nature of paleoclimate observations and networks (PPEs; von Storch et al., 2004; Smerdon, 2012), and may be as important for explaining reconstruction skill and bias patterns in paleoclimate reconstructions (Smerdon et al., 2011b) than the widely-debated differences in statistical reconstruction methodology (Christiansen, 2011; Smerdon et al., 2011a,b; Smerdon, 2012; Tingley et al., 2012). More sophisticated PPEs which realistically simulate sensor, archive and observational components of proxy system models, may help focus paleoclimatic change detection and attribution studies (Smerdon et al., 2011b) on key regions, types of observations, with required reproducibility, signal interpretability, chronological resolution, precision, and accuracy. A generalized framework that might

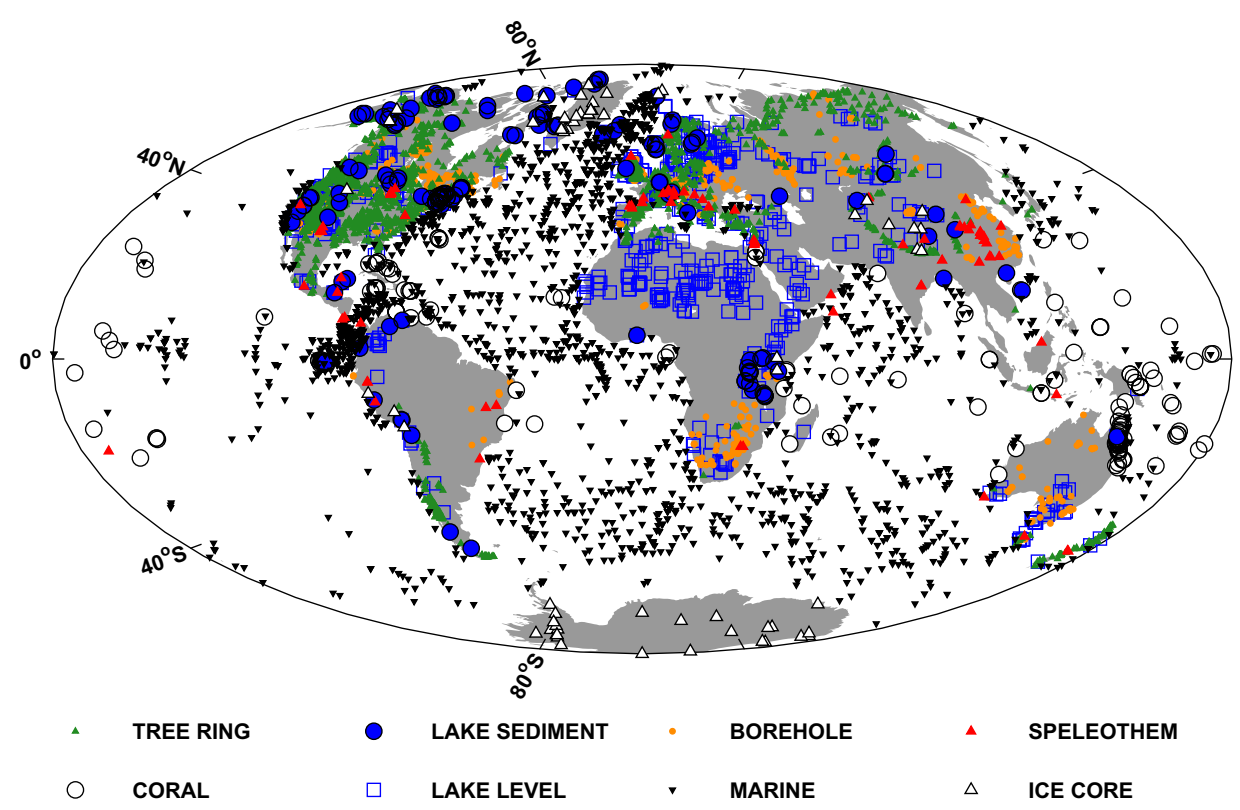

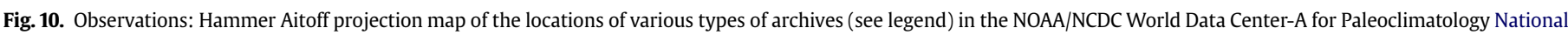
Climatic Data Center (2012). 
be used for paleoclimatic observing system simulation experiments is illustrated with remote sensing observations (which have some of the features of proxy systems) in Berliner et al. (2003).

\subsection{Examine the behavior of proxy systems under extreme conditions}

One of the roles of paleoclimatology is to better define the natural variability of the climate system on timescales longer than is possible using direct observations of climatic variables (Meko et al., 2007), and for recurrence interval of rare but extreme events (Frappier et al., 2007a). Both of these goals may help better resolve climate sensitivity to external radiative forcing (Schneider von Deimling et al., 2006). However, this often requires that the signal interpretation be valid for amplitude or frequency extrapolation beyond what is known from process studies or modern observations of the proxy system (Nyberg et al., 2007, 2008; Frappier et al., 2007b; Neu, 2008). Use of realistic proxy system models in signal interpretation analyses may help recover true signal amplitude despite smoothing or signal diffusion effects of the sensor, archive or observational process. Realistic proxy system models may thus help identify and potentially recover reconstructed amplitudes and uncertainties that fall outside of validation ranges (Anchukaitis et al., 2012; Feng et al., 2012; Gagan et al., 2012; Mann et al., 2012).

\subsection{Model the total uncertainty in the response of proxy systems to environmental forcing, and its expression in paleoclimatic reconstructions}

Proxy system models in their forward sense can be used in a reconstruction context to more fully explore the limitations on the retrievable climatic information content of the paleodata, given the complexities of the data formation process. In contrast to linearempirical reconstruction methods, which only explicitly acknowledge calibration uncertainty, forward models used within a probabilistic framework can account automatically for uncertainty due to multivariate climate interactions (Yu et al., 2012; Tolwinski-Ward et al., 2013b), non-climatic influences on the sensor (Garreta et al., 2010), and nonlinearities in the sensor's response to climate (Tolwinski-Ward et al., 2013b). In addition, Monte Carlo pseudoproxy reconstruction experiments with various components of the forward model included can also be compared to analyze the relative importance of various sources of reconstruction or interpretational uncertainties (Evans, 2007; Carré et al., 2012). We need to deploy proxy system modeling and model-observational comparisons on regional-to-global scales to assess the degree to which there are large-scale, systematic patterns of uncertainty in space, time and frequency. These results may then be used to constrain interpretation of paleoclimatic reconstructions given total uncertainty in their development. Conversely, the application of sophisticated reconstruction frameworks developed in oceanography and meteorology to assimilate higher signal-to-noise ratio and more densely-sampled fields to paleoclimatic observations and research questions (Allan et al., 2011; Compo et al., 2011) may provide a stiff and therefore useful test of their strengths and weaknesses.

\section{Conclusion}

Proxy systems may be multivariate, nonlinear, seasonal and spectral filters of the environmental conditions we seek to model and mechanistically understand. Intermediate-class proxy system models may be employed to represent and leverage the nature of paleo-observations to more realistically assess observing network design, facilitate signal interpretation, inform multivariate paleoenvironmental reconstructions, and more realistically diagnose and distinguish systematic and random uncertainties at all stages of these efforts. Advances in these areas will arise from close collaboration between proxy system scientists, paleoclimatologists, statisticians, and modelers to further develop existing and new proxy system models, couple them to climate system models, conduct detailed cross comparisons, and exploit the results to better inform and interpret paleoclimatic reconstructions.

\section{Acknowledgments}

We thank Mark A. Cane, Alexey Kaplan and Malcolm K. Hughes for encouraging the development of this research; Heinz Wanner, PAGES and the 18th INQUA Congress (Bern, 2011) for the opportunity to present these ideas in synthesis; and T. Horscoft and $\mathrm{N}$. Roberts for guidance and editorial suggestions. Two anonymous reviewers made insightful and constructive comments that improved the depth, breadth and clarity of the manuscript. We are grateful to M.B. Blumenthal and M. Bell for the IRI Data Libary and Ingrid software used to make Fig. 2. MNE and DMT were funded by NOAA/C2D2 grant NA10OAR4310115; SETW gratefully acknowledges support from an American Association of University Women Dissertation Fellowship. Work cited in this review was supported by NSF grants 0349356, 0724802 and 0902715, NOAA grants NA06OAR4310115 and NA08OAR4310682, and the University of Arizona's Department of Geosciences and Institute of the Environment.

\section{References}

Allan, R., Brohan, P., Compo, G.P., Stone, R., Luterbacher, J., Bronniman, S., 2011. The International Atmospheric Circulation Reconstructions over the Earth (ACRE) initiative. Bull. Am. Meteorol. Soc. 92 (11), 1421-1425. doi:10./cp-8433-2012.

Anchukaitis, K.J., Evans, M.N., 2010. Tropical cloud forest climate variability and the demise of the Monteverde Golden Toad. Proc. Nat. Acad. Sci.. http://dx.doi.org/ 10.1073/pnas.0908572107.

Anchukaitis, K.J., Tierney, J.E., 2012. Identifying coherent spatiotemporal modes in time-uncertain proxy paleoclimate records. Clim. Dyn., 1423-1441. http:// dx.doi.org/10.1007/s00382-012-1483-0.

Anchukaitis, K.J., Evans, M.N., Kaplan, A., Vaganov, E.A., Grissino-Mayer, H.D. Hughes, M.K., Cane, M.A., 2006. Forward modeling of regional-scale tree-ring patterns in the southeastern United States and the recent influence of summer drought. Geophys. Res. Lett. 33, L04705. http://dx.doi.org/10.1029/ 2005GL025050.

Anchukaitis, K.J., Evans, M.N., Wheelwright, N.T., Schrag, D.P., 2008. Stable isotope chronology and climate signal calibration in neotropical montane cloud forest trees. J. Geophys. Res. 113, G03030. http://dx.doi.org/10.1029/2007JG000613.

Anchukaitis, KJ., et al., 2012. Tree rings and volcanic cooling. Nat. Geosci. 5, 836837. http://dx.doi.org/10.1038/ngeo1645.

Baker, A., Bradley, C., 2010. Modern stalagmite $\delta^{18} \mathrm{O}$ : instrumental calibration and forward modelling. Glob. Planet. Change 71 (3), 201-206.

Baker, A., Bradley, C., Phipps, S.J., Fischer, M., Fairchild, I.J., Fuller, L., Spötl, C., Azcurra, C., 2012. Millennial-length forward models and pseudoproxies of stalagmite $\delta^{18} \mathrm{O}$ : an example from NW Scotland. Clim. Past 8 (4), 1153-1167. http://dx.doi.org/10.5194/cp-8-1153-2012.

Barbour, M.M., Roden, J.S., Farquhar, G.D., Ehleringer, J.R., 2004. Expressing leaf water and cellulose oxygen isotope ratios as enrichment above source water reveals evidence of a Péclet effect. Oecologia 138, 426-435. http://dx.doi.org/ 10.1007/s00442-003-1449-3.

Benestad, R.E., Hanssen-Bauer, I., Førland, E.J., 2007. An evaluation of statistical models for downscaling precipitation and their ability to capture long-term trends. Int. J. Clim. 27, 649-665. http://dx.doi.org/10.1002/joc.1421.

Berliner, L.M., Milliff, Wikle, C.K., 2003. Bayesian hierarchical modeling of air-sea interaction. J. Geophys. Res. 108 (C4), 3104. http://dx.doi.org/10.1029/ 2002JC001413.

Birks, H.J.B., 1995. In: Maddy, D., Brew, J.S. (Eds.), Quantitative Palaeoenvironmental Reconstructions, in Statistical Modelling of Quaternary Science Data. Quaternary Research Association, Cambridge, UK, pp. 161-254.

Blaauw, M., Christen, J.A., 2011. Flexible paleoclimate age-depth models using an autoregressive gamma process. Bayesian Anal. 6 (3), 457-474. http://dx.doi.org/ 10.1214/11-BA618.

Bradley, R.S., 1996. Are there optimum sites for global paleotemperature reconstruction? In: Jones, P.D., Bradley, R., Jouzel, J. (Eds.), Climatic Variations and Forcing Mechanisms of the Last 2000 Years, NATO ASI Ser. I: Global Environmental Change, vol. 41. Springer-Verlag, New York, pp. 603-624. 
Bradley, R.S., 2011. Dendrochronology: Progress and Prospects, Developments in Paleoenvironmental Research. In: High Resolution Paleoclimatology, vol. 11. Springer, New York, pp. 3-16. (Chapter).

Bretherton, F.P., McWilliams, J.C., 1980. Estimations from irregular arrays. Rev. Geophys. 18, 789-812.

Brienen, R.J.W., Helle, G., Pons, T.L., Guyot, J.-L., Gloor, M., 2012. Oxygen isotopes in tree rings are a good proxy for Amazon precipitation and El Niño-Southern Oscillation variability. Proc. Natl. Acad. Sci. U. S. A.. www.pnas.org/doi/10.1073/ pnas.1205977109.

Bronk Ramsey, C., 2008. Deposition models for chronological records. Quat. Sci. Rev. 27, 42-60. http://dx.doi.org/10.1016/j.quatscirev.2007.01.019.

Bronk Ramsey, C., 2009. Bayesian analysis of radiocarbon dates. Radiocarbon 51 (1), 337-360.

Brönnimann, S., Mariani, I., Schwikowski, M., Auchmann, R., Eichler, A., 2012. Simulating the temperature and precipitation signal in an Alpine ice core. Clim. Past Discuss. 8 (6), 6111-6134. http://dx.doi.org/10.5194/cpd-8-6111-2012.

Brown, J., Tudhope, A.W., Collins, M., McGregor, H.V., 2008. Mid-Holocene ENSO: issues in quantitative model-proxy data comparisons. Paleoceanography 23, PA3202. http://dx.doi.org/10.1029/2007PA001512.

Burgess, P.M., Wright, V.P., 2003. Numerical forward modeling of carbonate platform dynamics: an evaluation of complexity and completeness in carbonate strata. J. Sed. Res. 73 (5), 637-652.

Carré, M., Sachs, J.P., Wallace, J.M., Favier, C., 2012. Exploring errors in paleoclimate proxy reconstructions using Monte Carlo simulations: paleotemperature from mollusk and coral geochemistry. Clim. Past. 8, 433-450. http://dx.doi.org/ 10.5194/cp-8-433-2012.

Chatfield, C., 1989. The Analysis of Times Series: an Introduction, fourth ed. Chapman and Hall, London, p. 241.

Christiansen, B., 2011. Reconstructing the NH mean temperature: can underestimation of trends and variability be avoided? J. Clim. 24, 674-692.

Cohen, A.S., 2003. Paleolimnology: the History and Evolution of Lake Systems. Oxford Univ Press, ISBN 0-19-513353-6.

Cole, J.E., Cook, E.R., 1998. The changing relationship between ENSO variability and moisture balance in the continental United States. Geophys. Res. Lett. 25, 45294532.

Compo, G.P., et al., 2011. The twentieth century reanalysis project. Quat. J. Royal Met. Soc. 137 (Part A), 1-28. http://dx.doi.org/10.1002/qj.776.

Conroy, J.L., Overpeck, J.T., Cole, J.E., Shanahan, T.M., Steinitz-Kannan, M., 2008. Holocene changes in eastern tropical Pacific climate inferred from a Galápagos lake sediment record. Quat. Sci. Rev. 27 (11), 1166-1180.

Cook, E.R., Kairiukstis, L., 1990. Methods of Dendrochronology: Applications in the Environmental Sciences. Kluwer, Boston, p. 394.

Cook, E.R., Pederson, N., 2011. Uncertainty, emergence and statistics in dendrochronology. In: Hughes, M.K., Swetnam, T.W., Diaz, H.F. (Eds.), 2011. Tree Rings and Climate: Sharpening the Focus, Developments in Environmental Research, vol. 11. Springer, New York, pp. 77-112. (Chapter 4).

Cook, E.R., Briffa, K.R., Meko, D.M., Graybill, D.A., Funkhouser, G., 1995. The segment length curse in long tree-ring chronology development for palaeoclimatic studies. Holocene 5, 229-235.

Cook, E.R., Meko, D.M., Stahle, D.W., Cleaveland, M.K., 1999. Drought reconstructions for the continental United States. J. Clim. 12, 1145-1162.

D’Arrigo, R.D., Wilson, R., Liepert, B., Cherubini, P., 2008. On the 'Divergence Problem' in Northern Forests: a review of the tree-ring evidence and possible causes. Glob. Planet. Change 60, 289-305. http://dx.doi.org/10.1016/j.gloplacha.2007.03.004.

Douglass, A., 1919. Climatic Cycles and Tree-growth. Publication Number 289. Carnegie Institution of Washington.

Douglass, A.E., 1941. Crossdating in dendrochronology. J. For. 39 (10), 825-831.

Evans, M.N., 2007. Toward forward modeling for paleoclimatic proxy signal calibration: a case study with oxygen isotopic composition of tropical woods. Geochem. Geophys. Geosyst. 8, Q07008. http://dx.doi.org/10.1029/ 2006GC001406.

Evans, M.N., Kaplan, A., Cane, M.A., 1998. Optimal sites for coral-based reconstruction of sea surface temperature. Paleoceanography 13, 502-516.

Evans, M.N., Fairbanks, R.G., Rubenstone, J.L., 1999. The thermal oceanographic signal of El Niño reconstructed from a Kiritimati Island coral. J. Geophys. Res. $104,13,409-13,421$

Evans, M.N., Kaplan, A., Cane, M.A., 2000. Intercomparison of coral oxygen isotope data and historical sea surface temperature (SST): potential for coral-based SST field reconstructions. Paleoceanography $15,551-562$.

Evans, M.N., Kaplan, A., Cane, M.A., 2002. Pacific sea surface temperature field reconstruction from coral $\delta^{18} \mathrm{O}$ data using reduced space objective analysis. Paleoceanography 17. http://dx.doi.org/10.1029/2000PA000,590.

Evans, M.N., Reichert, B.K., Kaplan, A., Anchukaitis, K.J., Vaganov, E.A., Hughes, M.K., Cane, M.A., 2006. A forward modeling approach to paleoclimatic interpretation of tree-ring data. J. Geophys. Res. 111, G03008. http://dx.doi.org/10.1029/ 2006JG000166.

Fairbanks, R.G., Evans, M.N., Rubenstone, J.L., Mortlock, R.A., Broad, K., Moore, M.D., Charles, C.D., 1997. Evaluating climate indices and their geochemical proxies measured in corals. Coral Reefs 16, S93-S100.

Feng, W., Banner, J.L., Guilfoyle, A.L., Musgrove, M., James, E.W., 2012. Oxygen isotope fractionation between drip water and speleothem calcite: a 10-year monitoring study, central Texas, USA. Chem. Geol. 304-305, 53-67. http:// dx.doi.org/10.1016/j.chemgeo.2012.02.004.

Forster, V., amd Ramaswamy, P., et al., 2007. Changes in atmospheric constituents and in radiative forcing. In: Solomon, S., Qin, D., Manning, M., Chen, Z.,
Marquis, M., Averyt, K.B., Tignor, M., Miller, H.L. (Eds.), Climate Change 2007: the Physical Science Basis. Cambridge University Press, p. 996.

Frappier, A., Knutson, T., Liu, K.-B., Emanuel, K., 2007a. Perspective: coordinating paleoclimate research on tropical cyclones with hurricane-climate theory and modelling. Tellus 39A, 529-537. http://dx.doi.org/10.1111/j.16000870.2007.00250.x.

Frappier, A.B., Sahagian, D., Carpenter, S.J., González, L.A., Frappier, B.R., 2007b. Stalagmite stable isotope record of recent tropical cyclone events. Geology 25 (2), 111-114. http://dx.doi.org/10.1130/G23145A.1.

Fritts, H.C., 1976. Tree Rings and Climate. Academic Press, New York

Gagan, M.K., Dunbar, G.B., Suzuki, A., 2012. The effect of skeletal mass accumulation in porites on coral sr/ca and $\delta^{18} \mathrm{O}$ paleothermometry. Paleoceanography 27 , PA1203. http://dx.doi.org/10.1029/2011PA002215.

Garreta, V., Miller, P.A., Guiot, J., Hély, C., Brewer, S., Sykes, M.T., Litt, T., 2010 A method for climate and vegetation reconstruction through the inversion of a dynamic vegetation model. Clim. Dyn. 35, 371-389. http://dx.doi.org/10.1007/ s00382-009-0629-1.

González-Rouco, J.F., Beltrami, H., Zorita, E., von Storch, H., 2006. Simulation and inversion of borehole temperature profiles in surrogate climates: spatial distribution and surface coupling. Geophys. Res. Lett. 33, L01703. http://dx.doi.org 10.1029/2005GL024693

Graham, N.E., Hughes, M.K., 2007. Reconstructing the Mediaeval low stands of Mono Lake, Sierra Nevada, California, USA. The Holocene 17 (8), 1197-1210. http://dx.doi.org/10.1177/095683607085126.

Graham, N.E., Ammann, C.M., Fleitmann, D., Cobb, K.M., Luterbacher, J., 2011. Support for global climate reorganization during the "Medieval Climate Anomaly". Clim. Dyn. 37, 1217-1245 http://dx.doi.org/10.1007/s00382-010-0914-z.

Graham, N.E., et al., 2007. Tropical Pacific - mid-latitude teleconnections in medieval times. Clim. Change 83 (1), 241-285.

Griffin, D., Meko, D., Touchan, R., Leavitt, S., Woodhouse, C., 2011. Latewood chronology development for summer-moisture reconstruction in the us southwest. Tree-Ring Res. 67 (2), 87-101.

Grossman, E.L., Ku, T.-L., 1986. Oxygen and carbon isotopic fractionation in biogenic aragonite: temperature effects. Chem. Geol. 59, 59-74.

Guiot, J., Wu, H.B., Garreta, V., Hatté, C., Magny, M., 2009. A few prospective ideas on climate reconstruction: from a statistical single proxy approach towards a multi-proxy and dynamical approach. Clim. Past 5, 571-583. www.clim-past. net/5/571/2009/.

Guyette, R.P., 1991. Monitoring Environmental Chemistry with Tree Rings (Ph.D. thesis). University of Missouri-Columbia, p. 154.

Hargreaves, J.C., Paul, A., Ohgaito, R., Abe-Ouchi, A., Annan, J.D., 2011. Are paleoclimate model estimates consistent with the MARGO data synthesis? Clim. Past 7, 917-933 http://dx.doi.org/10.5194/cp-7-917-2011.

Hargreaves, J.C., Annan, J.D., Yoshimori, M., Abe-Ouchi, A., 2012. Can the Last Glacial Maximum constrain climate sensitivity? Geophys. Res. Lett. 39 (24).

Haslett, J., Whiley, M., Bhattacharya, S., Salter-Townshend, M., Wilson, S.P. Allen, J.R.M., Huntley, B., Mitchell, F.J.G., 2006. Bayesian palaeoclimate reconstruction. J. Royal Stat. Soc. Ser. A 169, 395-430. http://dx.doi.org/10.1111/ j.1467-985X.2006.00429.x.

Hegerl, G.C., Zwiers, F.W., Braconnot, P., Gillett, N.P., Luo, Y., Marengo Orsini, J.A., Nicholls, N., Penner, J.E., Stott, P.A., 2007. Understanding and attributing climate change. In: Solomon, S., Qin, D., Manning, M., Chen, Z., Marquis, M., Averyt, K.B. Tignor, M., Miller, H.L. (Eds.), Climate Change 2007: the Physical Science Basis. Cambridge University Press, p. 996.

Huang, S., Pollack, H.N., Shen, P.-Y., 2000. Temperature trends over the past five centuries reconstructed from borehole temperatures. Nature 403, 756-758.

Hughes, M.K., 2011. Dendroclimatology in high-resolution paleoclimatology. In: Hughes, M.K., Swetnam, T.W., Diaz, H.F. (Eds.), 2011. Dendrochronology: Progress and Prospects, Developments in Paleoenvironmental Research, vol. 11. Springer, New York, pp. 17-34, 365 pp.

Hughes, M.K., Ammann, C.M., 2009. The future of the past - an earth system framework for high resolution paleoclimatology: editorial essay. Clim. Change 94, 247-259. http://dx.doi.org/10.1007/s10584-009-9588-0.

Hughes, M.K., Salzer, M.W., 2009. Methuselah Walk Update - PILO. http:// hurricane.ncdc.noaa.gov/pls/paleox/f?p=519:1:1102049481541696::::P1 STUDY_ID:8518 (accessed 16.04.13.).

Huntley, B., 2012. Reconstructing palaeoclimates from biological proxies: some often overlooked sources of uncertainty. Quat. Sci. Rev. 31, 1-16. http:// dx.doi.org/10.1016/jquascirev.2011.11.006.

Huybers, P., Curry, W., 2006. Links between annual, Milankovitch, and continuum temperature variability. Nature 441, 329-332. http://dx.doi.org/10.1038/ nature04745.

IODP/TAMU, 2010. IODP-USIO: Data \& Core Samples: Core Images. URL: http://iodp. tamu.edu/janusweb/imaging/photo.shtml (accessed 30.08.12.)

Jansen, E., et al., 2007. Palaeoclimate. In: Solomon, S., Qin, D., Manning, M., Chen, Z., Marquis, M., Averyt, K.B., Tignor, M., Miller, H.L. (Eds.), Climate Change 2007: the Physical Science Basis, Contribution of Working Group I to the Fourth Assessment Report of the Intergovernmental Panel on Climate Change. Cambridge University Press, New York, NY USA, pp. 434-497.

Kanamitsu, M., Ebusuzaki, W., Woollen, J., Yang, S.-K., Hnilo, J.J., Fiorino, M., Potter, G.L., 2002. NCEP-DOE AMIP-II reanalysis (r-2). Bull. Am. Meteorol. Soc. 83 (11), 1631-1643.

Kaplan, A., Cane, M.A., Kushnir, Y., Clement, A.C., Blumenthal, M.B., Rajagopalan, B., 1998. Analyses of global sea surface temperature 1856-1991. J. Geophys. Res. 103 (C9), 18,567-18,589. 
Khatiwala, S., Visbeck, M., Schlosser, P., 2001. Age tracers in an ocean GCM. Deep Sea Res. Part I 48, 1423-1441.

Kipp, N., 1976. New transfer function for estimating past sea surface conditions from sea-bed distribution of planktonic foraminiferal assemblages in the North Atlantic. Geol. Soc. Am. Mem. 145, 3-41.

Klauenberg, K., Blackwell, P.G., Buck, C.E., Mulvaney, R., Rothlisberger, R. Wolff, E.W., 2011. Bayesian glaciological modelling to quantify uncertainties in ice core chronologies. Quat. Sci. Rev. 30, 2961-2975. http://dx.doi.org/10.1016/ j.quatscirev.2011.03.008.

Laboratory of Tree-Ring Research, 2001. Extending a chronology based on living trees further back in time through crossdating. In: Paleo Slide Set: Tree Rings: Ancient Chronicles of Environmental Change. URL: http://www.ncdc.noaa.gov/ paleo/slides/slideset/18/18_355_slide.html (accessed 30.08.12.).

Leavitt, S.W., 1994. Major wet interval in White Mountains medieval warm period evidenced in $\delta^{13} \mathrm{C}$ of bristlecone pine tree rings. Clim. Change 26, 299-307.

Leavitt, S.W., 2013. $\delta^{18} \mathrm{C}$ Data from Bristlecone Pine Tree Rings Reported in Leavitt et al (1994), Pers. Comm. to S.E. Tolwinski-Ward, March 2013.

LeGrande, A.N., Schmidt, G.A., 2006. Global gridded data set of the oxygen isotopic composition in seawater. Geophys. Res. Lett. 33, L12,604. http://dx.doi.org/ 10.1029/2006GL026011.

LeGrande, A.N., Schmidt, G.A., 2008. Ensemble, water isotope-enabled, coupled general circulation modeling insights into the 8.2 ka event. Paleoceanography 23, PA3207. http://dx.doi.org/10.1029/2008PA001610.

LeGrande, A.N., Schmidt, G.A., 2009. Sources of Holocene variability of oxygen isotopes in paleoclimate archives. Clim. Past 5, 441-455. www.clim-past.net/5/ $441 / 2009$.

LeGrande, A.N., Schmidt, G.A., Shindell, D.T., Field, C.V., Miller, R.L., Koch, D.M., Faluvegi, G., Hoffmann, G., 2006. Consistent simulations of multiple proxy responses to an abrupt climate change event. Proc. Natl. Acad. Sci. U. S. A. 103 , 837-842. http://dx.doi.org/10.1073/pnas.0510095103.

Lough, J.M., 2004. A strategy to improve the contribution of coral data to highresolution paleoclimatology. Palaeogeog., Palaeoclim., Palaeoecol. 204 (1-2), 115-143.

Lough, J.M., Cooper, T.F., 2011. New insights from coral growth band studies in an era of rapid environmental change. Earth Sci. Rev. 108, 170-184. http:// dx.doi.org/10.1016/j.earscirev.2011.07.001.

Lyons, R.P., Kroll, C.N., Scholz, C.A., 2011. An energy-balance hydrologic model for the Lake Malawi Rift Basin, East Africa. Glob. Planet. Change 75 (1), 83-97.

Mahowald, N., Kohfeld, K., Hannson, M., Balkanski, Y., Harrison, S.P., Prentice, I.C. Schulz, M., Rodhe, H., 1999. Dust sources and deposition during the Last Glacia Maximum and current climate: a comparison of model results with paleodata from ice cores and marine sediments. J. Geophys. Res. 104 (D13), 15,895-15,916.

Mann, M.E., Bradley, R.S., Hughes, M.K., 1998. Global temperature patterns over the past five centuries: implications for anthropogenic and natural forcing of climate. Nature 392, 779-787.

Mann, M.E., Zhang, Z., Hughes, M.K., Bradley, R.S., Miller, S.K., Rutherford, S., 2008 Proxy-based reconstructions of hemispheric and global surface temperature variations over the past two millennia. Proc. Natl. Acad. Sci. U. S. A. 105 (36) 13,252-13,257. http://dx.doi.org/10.1073/pnas.0805721105.

Mann, M.E., Schmidt, G.A., Miller, S.K., LeGrande, A.N., 2009a. Potential biases in inferring Holocene temperature trends from long-term borehole information. Geophys. Res. Lett. 36, L05,708. http://dx.doi.org/10.1029/2008GL036354.

Mann, M.E., Zhang, Z., Rutherford, S., Bradley, R.S., Hughes, M.K., Shindell, D., Ammann, C., Faluvegi, G., Ni, F., 2009b. Global signatures and dynamical origin of the Little Ice Age and Medieval Climate Anomaly. Science 326, 1256-1260. http://dx.doi.org/10.1126/science.1177303.

Mann, M.E., Fuentes, J.D., Rutherford, S., 2012. Underestimation of volcanic cooling in tree-ring-based reconstructions of hemispheric temperatures. Nat. Geosci. 5, 202-205. http://dx.doi.org/10.1038/ngeo1394.

McCarroll, D., Loader, N.J., 2004. Stable isotopes in tree rings. Quat. Sci. Rev. 23, $771-801$.

Meehl, G.A., et al., 2007. Global climate projections. In: Solomon, S., Qin, D. Manning, M., Chen, Z., Marquis, M., Averyt, K.B., Tignor, M., Miller, H.L. (Eds.), Climate Change 2007: the Physical Science Basis. Cambridge University Press, p. 996.

Meese, D.A., Gow, A.J., Alley, R.B., Zielinski, G.A., Grootes, P.M., Ram, M., Taylor, K.C. Mayewski, P.A., Bolzan, J.F., 1997. The Greenland Ice Sheet Project 2 depth-age scale: methods and results. J. Geophys. Res. 102 (C12), 26,411-26,423.

Meko, D.M., Baisan, C.H., 2001. Pilot study of latewood-width of conifers as an indicator of variability of summer rainfall in the North American monsoon region. Int. J. Climatol. 21 (6).

Meko, D.M., Woodhouse, C.A., Baisan, C.A., Knight, T., Lukas, J.J., Hughes, M.K., 2007 Medieval drought in the upper Colorado River Basin. Geophys. Res. Lett. 34 L10,705. http://dx.doi.org/10.1029/2007GL029988.

Mix, A.C., Morey, A.E., Pisias, N., Hostetler, S.W., 1999. Foraminiferal faunal estimates of paleotemperature: circumventing the no-analog problem yields cool ice age tropics. Paleoceanography 14, 350-359.

Moberg, A., Sonechkin, D.M., Holmgren, K., Datsenko, N.M., Karlén, W., 2005. Highly variable Northern Hemisphere temperatures reconstructed from low- and high-resolution proxy data. Nature 433, 613-617.

Mölg, T., Cullen, N.J., Hardy, D.R., Kaser, G., Klok, L., 2009. Mass balance of a slope glacier on Kilimanjaro and its sensitivity to climate. Int. J. Clim. 28, 881-892. http://dx.doi.org/10.1002/joc.1589.

National Climatic Data Center, 2012. NCDC/WDCA-Paleo Site Map Datafiles. NOAA Paleoclimatology Program. ftp://ftp.ncdc.noaa.gov/pub/data/paleo/site_maps.
Neu, U., 2008. Is recent major hurricane activity normal? Nature 451 http:// dx.doi.org/10.1038/nature06576.

New, M., Hulme, M., Jones, P., 2000. Representing twentieth-century space-time climate variability. Part II: development of 1901-96 monthly grids of terrestrial surface climate. J. Clim. 12, 2217-2238. Version CRUTS2.1 (1901-2002) accessed via Internet: http://www.cru.uea.ac.uk/cru/data/hrg.htm (November 2006).

Nyberg, J., Malmgren, B.A., Winter, A., Jury, M.R., Kilbourne, K.H., Quinn, T.M., 2007. Low Atlantic hurricane activity in the late 1970s and 1980s compared to the past 270 years. Nature 447, 698-701. http://dx.doi.org/10.1038/nature05895.

Nyberg, J., Malmgren, B.A., Winter, A., Jury, M.R., Kilbourne, K.H., Quinn, T.M., 2008. Reply. Nature 451. http://dx.doi.org/10.1038/nature06577.

O'Neil, J.R., Clayton, R.N., Mayeda, T.K., 1969. Oxygen isotope fractionation in divalent metal carbonates. J. Chem. Phys. 51 (12), 5547-5558. http://dx.doi.org/ $10.1063 / 1.167982$.

Parnell, A.C., Buck, C.E., Doan, T.K., 2011. A review of statistical chronology models for high-resolution, proxy-based Holocene palaeoenvironmental reconstruction. Quat. Sci. Rev. 30, 2948-2960. http://dx.doi.org/10.1016/ j.quatscirev.2011.07.024

Reichert, B.K., Bengtsson, L., Akesson, O., 1999. A statistical modeling approach for the simulation of local paleoclimatic proxy records using general circulation model output. J. Geophys. Res. 104, 19,071-19,083.

Russon, T., Tudhope, A.W., Hegerl, G.C., Collins, M., Tindall, J., 2013. Inter-annual tropical pacific climate variability in an isotope-enabled $\mathrm{cgcm}$ : implications for interpreting coral stable oxygen isotope records of ENSO. Clim. Past Discuss. 9, 741-773. http://dx.doi.org/10.5194/cpd-9-741-2013.

Sachs, H.M., Webb III, T., Clark, D.R., 1977. Paleoecological transfer functions. Annu. Rev. Earth Planet. Sci. 5, 159-178.

Salzer, M.W., Hughes, M.K., Bunn, A.G., Kipfmueller, K.F., 2009. Recent unprecedented tree-ring growth in bristlecone pine at the highest elevations and possible causes. Proc. Natl. Acad. Sci. U. S. A. 106 (48), 20,348-20,553. http:// dx.doi.org/10.1073/pnas.0903029106.

Schmidt, G.A., 1999. Forward modeling of carbonate proxy data from planktonic foraminifera using oxygen isotope tracers in a global ocean model. Paleoceanography 14 (4), 482-497.

Schmidt, G.A., 2010. Enhancing the relevance of palaeoclimate model/data comparisons for assessments of future climate change. J. Quat. Sci. 25 (1), 79-87. http://dx.doi.org/10.1002/jqs.1314.

Schmidt, G.A., LeGrande, A.N., Hoffmann, G., 2007. Water isotope expressions of intrinsic and forced variability in a coupled ocean-atmosphere model. J. Geophys. Res. Atmos. 112 (D10103). http://dx.doi.org/10.1029/2006JD007781.

Schmidt, G.A., et al., 2012. Climate forcing reconstructions for use in PMIP simulations of the Last Millennium (v1.1). Geosci. Mod. Devel. 5 (1), 185-191.

Schmidt, G.A., et al., 2013. Using paleo-climate comparisons to constrain future projections in CMIP5. Clim. Past Discuss. 9, 775-835. http://dx.doi.org/10.5194/ cpd-9-775-2013.

Schmittner, A., Urban, N.M., Shakun, J.D., Mahowald, N.M., Clark, P.U., Bartlein, P.J., Mix, A.C., Rosell-Melé, A., 2011. Climate sensitivity estimated from temperature reconstructions of the Last Glacial Maximum. Science 334 (6061), 1385-1388.

Schneider von Deimling, T.S., Held, H., Ganopolski, A., Rahmstorf, S., 2006. Climate sensitivity estimated from ensemble simulations of glacial climate. Clim. Dyn.. http://dx.doi.org/10.1007/s00382-006-0126-8.

Scholz, D., Hoffman, D.L., 2011. StalAge- an algorithm designed for construction of speleothem age models. Quat. Geochron. 6, 369-382.

Schweingruber, F., Fritts, H., Bräker, O., Drew, L., Schär, E., 1978. The X-ray technique as applied to dendroclimatology. Tree-Ring Bull. 38, 61-91.

Severinghaus, J.P., Brook, E.J., 1999. Abrupt climate change at the end of the Last Glacial period inferred from trapped air in polar ice. Science 286, 930-934.

Shanahan, T.M., Overpeck, J.T., Sharp, W.E., Scholz, C.A., Arko, J.A., 2007. Simulating the response of a closed-basin lake to recent climate changes in tropical West Africa (Lake Bosumtwi, Ghana). Hydrol. Proc. 21 (13), 1678-1691.

Slonosky, V.C., Jones, P.D., Davies, T.D., 2001. Atmospheric circulation and surface temperature in Europe from the 18th century to 1995. Int. J. Clim. 21, 63-75.

Smerdon, J.E., 2012. Climate models as a test bed for climate reconstruction methods: pseudoproxy experiments. WIRES Clim. Change 3, 63-77. http:// dx.doi.org/10.1002/wcc.149.

Smerdon, J.E., Kaplan, A., Chang, D., Evans, M.N., 2011a. A pseudoproxy evaluation of the CCA and RegEM methods for reconstructing climate fields of the last millennium. J. Clim. 24, 1284-1309. http://dx.doi.org/10.1175/2010JCL14110.1.

Smerdon, J.E., Kaplan, A., Zorita, E., González-Rouco, J.F., Evans, M.N., 2011b. Spatial performance of four climate field reconstruction methods targeting the Common Era. Geophys. Res. Lett. 38, L11,705. http://dx.doi.org/10.1029/ 2011 GL047372.

Somes, C.J., et al., 2010. Simulating the global distribution of nitrogen isotopes in the ocean. Glob. Biogeochem. Cy. 24, GB4019. http://dx.doi.org/10.1029/ 2009 GB003767.

Steinman, B.A., Rosenmeier, M.F., Abbott, M.B., Bain, D.J., 2010. The isotopic and hydrologic response of small, closed-basin lakes to climate forcing from predictive models: application to paleoclimate studies in the upper Columbia River basin. Limnol. Oceanogr. 55 (6), 2131-2145.

Steinman, B.A., Abbott, M.B., Nelson, D.B., Stansell, N.D., Bain, D.J., Rosenmeier, M.F., Finney, B.P., 2012. Isotopic and hydrologic responses of small, closed lakes to climate variability: comparison of measured and modeled lake level and sediment core oxygen isotope records. Geochim. Cosmochim. Acta 105, 455-471. http://dx.doi.org/10.1016/j.gca.2012.11.026. 
Stokes, M.A., Smiley, T.L., 1968. An Introduction to Tree-ring Dating. University of Arizona Press, Tucson, AZ. Reprinted 1995.

Stoll, H.M., Müller, W., Prieto, M., 2012. I-STAL, a model for interpretation of $\mathrm{Mg} / \mathrm{Ca}$, $\mathrm{Sr} / \mathrm{Ca}$ and $\mathrm{Ba} / \mathrm{Ca}$ variations in speleothems and its forward and inverse application on seasonal to millennial scales. Geochem. Geophys. Geosyst. 13 (1), Q09,004. http://dx.doi.org/10.1029/2012GC004183.

Taylor, K.E., Stouffer, R.J., Meehl, G.A., 2012. An overview of CMIP5 and the experiment design. Bull. Am. Meteorol. Soc. 93, 485-498. http://dx.doi.org/10.1016/ BAMS-D-11-00094.1.

Thompson, D.M., Ault, T.R., Evans, M.N., Cole, J.E., Emile-Geay, J., 2011. Comparison of observed and simulated tropical climate trends using a forward model of coral $\delta^{18} \mathrm{O}$. Geophys. Res. Lett. 38, L14,706. http://dx.doi.org/10.1029/ 2011 GL048224.

Thompson, D.M., Ault, T.R., Evans, M.N., Cole, J.E., Emile-Geay, J., LeGrande, A., 2013. Coral-CGCM comparison highlights role of salinity in long-term trends. In: Braconnot, P., Brierley, C., Harrison, S.P., von Gunten, L. (Eds.), 2013. El Niño Southern Oscillation: Observation and Modeling, PAGES News, 21 (2) (in press).

Thompson, L.G., 2000. Ice core evidence for climate change in the Tropics: implications for our future. Quat. Sci. Rev. 19, 19-35.

Tierney, J.E., Lewis, S.C., Cook, B.I., LeGrande, A.N., Schmidt, G.A., 2011. Model, proxy and isotopic perspectives on the East African Humid Period. Earth Planet. Sci. Lett. 307 (1), 103-112.

Tingley, M.P., Craigmile, P.F., Haran, M., Li, B., Mannshardt, E., Rajaratnam, B., 2012. Piecing together the past: statistical insights into paleoclimatic reconstructions. Quat. Sci. Rev. 35, 1-22. http://dx.doi.org/10.1016/j.quascirev.2012.01.012.

Tolwinski-Ward, S.E., Evans, M.N., Hughes, M.K., Anchukaitis, K.J., 2011a. An efficient forward model of the climatic controls on intramural variation in tree-ring width. Clim. Dyn. 36, 2419-2439. http://dx.doi.org/10.1007/s00382-010-0945-5.

Tolwinski-Ward, S.E., Evans, M.N., Hughes, M.K., Anchukaitis, K.J., 2011b. Erratum to: an efficient forward model of the climatic controls on intramural variation in tree-ring width. Clim. Dyn.. http://dx.doi.org/10.1007/s00382-011-1062-9.

Tolwinski-Ward, S.E., Anchukaitis, K.J., Evans, M.N., 2013a. Bayesian parameter estimation and interpretation for an intermediate model of tree-ring width. Clim. Past. Discuss. 9, 615-645. http://dx.doi.org/10.5194/cpd-9-615-2013.

Tolwinski-Ward, S.E., Tingley, M.P., Evans, M.N., Nychka, D.W., Hughes, M.K., 2013b. Probabilistic Reconstructions of Local Temperature and Soil Moisture via Inversion of a Mechanisms-based Model of Tree-ring Growth (in preparation).

Trenberth, K.E., 1995. Climate System Modeling. Cambridge University Press, Cambridge, UK, p. 788.

Truebe, S., Ault, T.R., Cole, J.E., 2010. A forward model of cave dripwater $\delta^{18} \mathrm{O}$ and application to speleothem records. IOP Conf. Ser. Earth Environ. Sci.. http:// dx.doi.org/10.1088/1755-1315/9/1/012022.

Vaganov, E.A., Hughes, M.K., Shashkin, A.V., 2006. Growth Dynamics of Conifer Tree Rings: Images of Past and Future Environments. In: Ecol. Studies, vol. 183. Springer-Verlag, Berlin/Heidelberg/New York.

Vaganov, E.A., Anchukaitis, K.J., Evans, M.N., 2011. How well understood are the processes that create dendroclimatic records? A mechanistic model of the climatic control on conifer tree-ring growth dynamics ( In: Hughes, M.K. Swetnam, T.W., Diaz, H.F. (Eds.), 2011. Tree Rings and Climate: Sharpening the Focus, Developments in Environmental Research, vol. 11. Springer, New York, pp. 37-76 Chapter 3).

Veron, J.E.N., 2000. Corals of the World, vol. 1. Australian Institute of Marine Science, Townsville MC, Queensland, Australia. URL: http://coral.aims.gov.au/ speciesPages/html/key/structure.html (accessed 30.08.12.).

Viau, A.E., Ladd, M., Gajewski, K., 2012. The climate of North America during the past 2000 years reconstructed from pollen data. Glob. Planet. Change 84-85, 75-83.

Villalba, R., D’Arrigo, R.D., Cook, E.R., Wiles, G., Jacoby, G.C., 2001. Decadal-scale climatic variability along the extra-tropical western coast of the Americas ove past centuries inferred from tree-ring records. In: Markgraf, V. (Ed.), Interhemispheric Climate Linkages. Cambridge University Press, Cambridge, UK, pp. 155-172.

von Storch, H., Zorita, E., Jones, J.M., Dimitriev, Y., González-Rouco, J.F, Tett, S.F.B., 2004. Reconstructing past climate from noisy data. Science 306 , $679-682$.

Vuille, M., Werner, M., 2005. Stable isotopes in precipitation recording South American summer monsoon and ENSO variability: observations and model results. Clim. Dyn. 25, 401-413.

Wackerbarth, A., Scholz, D., Fohlmeister, J., Mangini, A., 2010. Modelling the $\delta^{18} \mathrm{O}$ value of cave drip water and speleothem calcite. Earth Planet. Sci. Lett. 299 (3), 387-397.

Wahl, E.R., Diaz, H.F., Ohlwein, C., 2012. A pollen-based reconstruction of summer temperature in central North America and implications for circulation patterns during medieval times. Glob. Planet. Change 84-85, 66-74.

Wallace, J.M., 1996a. Observed climatic variability: time dependence. In: Decadal Climate Variability: Dynamics and Predictability. NATO ASI Series I: Global Environmental Change, vol. 44. Springer-Verlag, pp. 1-30.

Wallace, J.M., 1996b. Observed climatic variability: spatial structure. In: Decadal Climate Variability: Dynamics and Predictability. NATO ASI Series I: Global Environmental Change, vol. 44. Springer-Verlag, pp. 31-81.

Weber, J.N., Woodhead, P.M.J., 1972. Temperature dependence of oxygen-18 concentration in reef coral carbonates. J. Geophys. Res. 77 (3), 463-473.

Wigley, T.M., Briffa, K.R., Jones, P.D., 1984. On the average value of correlated time series, with applications in dendroclimatology and hydrometeorology. J. Clim. Appl. Meteorol. 23, 201-213.

Wilby, R.L., Wigley, T.M.L., 1997. Downscaling general circulation model output: a review of methods and limitations. Progr. Phys. Geog. 21 (4), 530-548.

Williams, J.W. Shuman, B., 2008. Obtaining accurate and precise environmental reconstructions from the modern analog technique and North American surface pollen dataset. Quat. Sci. Rev. 27, 669-687.

Yu, S.-Y., Kang, Z., Zhou, W., 2012. Quantitative palaeoclimate reconstruction as an inverse problem: a Bayesian inference of late-Holocene climate on the eastern Tibetan Plateau from a peat cellulose $\delta^{18} \mathrm{O}$ record. The Holocene $22(4), 405-$ 412. http://dx.doi.org/10.1177/0959683611425544. 